\title{
Aluminum Modifies the Properties of Alzheimer's Disease PHF $\tau$ Proteins in vivo and in vitro
}

\author{
Ryong-Woon Shin, Virginia M.-Y. Lee, and John Q. Trojanowski \\ The Department of Pathology and Laboratory Medicine, The Division of Anatomic Pathology, The University of \\ Pennsylvania School of Medicine, Philadelphia, PA 19104-4283
}

Hyperphosphorylated adult human CNS $\tau$ (PHF $\tau$ or A68) forms paired helical filaments (PHFs) in neurofibrillary tangles (NFTs), neuropil threads, and dystrophic neurites associated with senile plaques (SPs) during the progression of Alzheimer's disease (AD). While amyloid fibrils in SPs are composed of $\beta$-amyloid (A $\beta)$, NFTs and SPs contain similar associated components such as ubiquitin, $\alpha_{1}$-antichymotrypsin (ACT), apolipoprotein E (ApoE), heparan sulfate proteoglycans (HSPGs), and aluminum salts. Thus, SPs and NFTs may result from specific interactions between $P H F \tau, A \beta$, and these other components. In fact, intracerebral injections of PHFr induce co-deposits of $A \beta, A C T$, and ubiquitin (Shin et al., 1993). To examine this issue further, we probed interactions between $\mathrm{PHF}_{\tau}$, aluminum salts, and other plaque and tangle components.

We investigated in vivo interactions of $\mathrm{PHF}_{\boldsymbol{\tau}}$ and aluminum chloride $\left(\mathrm{AICl}_{3}\right)$ with other plaque and tangle components by injecting $\mathrm{PHF}_{\tau}$ with and without $\mathrm{AICl}_{3}$ into the rodent brain. PHF $\tau$ co-injected with $\mathrm{AlCl}_{3}$ formed aggregates that persisted much longer in the rat brain, and induced longer-lived codeposits of $A \beta$, ubiquitin, $A C T$, and $A p o E$ than $\mathrm{PHF}_{\tau}$ alone. Injections of PHF $\tau$ with $\mathrm{AlCl}_{3}$ also induced neurons near the injection site to acquire PHFr-like properties as monitored with antibodies (AT8, T3P, PHF1) that recognize defined PHF epitopes containing phosphoserine residues (Ser ${ }^{202}$, Ser ${ }^{396}$, Ser ${ }^{404}$ ). Injections of $\mathrm{AlCl}_{3}$ alone as well as injections of normal adult and fetal CNS $\tau$, several different synthetic peptides, neurofilament proteins, ACT, HSPGs, or ApoE with and without $\mathrm{AlCl}_{3}$ failed to induce co-deposits of $A \beta$ or alter the immunoreactivity of $\tau$ in rodent neurons.

To determine if aluminum salts interact directly and specifically with PHFr in situ, we pretreated sections of AD hippocampus with $10 \mathrm{mM} \mathrm{AICl}$ and then probed these sections by immunohistochemistry with antibodies to PHFr as well as

\footnotetext{
Received Jan. 28, 1994; revised June 1, 1994; accepted June 2, 1994.

We thank J. Martin, K. Robinson, V. V. Kumar, O. A. Kera, and M. Wiederhorn for assistance; J. I. Ko for comments; colleagues in the Departments of Pathology and Laboratory Medicine, Neurology, Psychiatry, and the Penn Alzheimer Disease Center Core for assistance in obtaining tissue samples; Dr. G. G. Pietra and Ms. J. Minda for assistance with electron microscopy; and the families of the patients who made our research possible. We also thank Drs. L. I. Binder, P. Davies, S Greenberg, B. Greenberg, R. Kisilevsky, M. Vandermeeren, and S. G. Younkin, who kindly provided antibodies; Dr. L. Otvos, Jr. for the peptides; and Drs. B Cooperman and $H$. Rubin for the recombinant human ACT. This work was supported by grants from the National Institutes of Health (National Institute on Aging).

Correspondence should be addressed to Dr. J. Q. Trojanowski, Department of Pathology and Laboratory Medicine, University of Pennsylvania School of Medicine, HUP/Maloney A009, Philadelphia, PA 19104-4283.
}

Copyright (C) 1994 Society for Neuroscience $0270-6474 / 94 / 147221-13 \$ 05.00 / 0$ to a number of other plaque and tangle components. Preincubation of these sections with $\mathrm{AlCl}_{3}$ diminished PHFt immunoreactivity in NFTs and SPs using the PHF $\tau$-specific antibodies AT8, T3P, and PHF1, while the immunoreactivity of other plaque and tangle proteins (A $\beta$, ubiquitin, ACT, HSPGs, ApoE) was not abolished. We also examined the effects of $\mathrm{AlCl}_{3}$ on $\mathrm{PHF}_{\tau}$ and normal adult human $\mathrm{CNS} \tau$ in vitro. $\mathrm{AlCl}_{3}$ had no effect on normal adult human CNS $\tau$, while increasing concentrations of $\mathrm{AlCl}_{3}$ (from 0.1 to $1.0 \mathrm{~mm}$ ) induced $\mathrm{PHF}_{\tau}$ to aggregate at the top of the stacking gel, and at high concentrations (0.3 and $1.0 \mathrm{~mm}$ ) of $\mathrm{AlCl}_{3}, \mathrm{PHF}_{\tau}$ completely failed to enter the gel.

These studies suggest that aluminum binds to PHFr, induces these proteins to aggregate, and retards their proteolysis. Further, since intracerebral injections of PHF $\boldsymbol{\tau}$ with and without $\mathrm{AlCl}_{3}$ in rats appear uniquely capable of inducing co-deposits of a number of proteins found in authentic AD SPs and NFTs (including $A \beta$, ubiquitin, $A C T$, and $A p o E$ ), we speculate that the contributions of $P H F \tau$ to plaque and tangle formation in AD may be modulated by aluminum.

[Key words: aluminum, tau proteins, PHFs, $\beta$-amyloid, A/zheimer's disease, neurofibrillary tangles]

The major histopathologic abnormalities that characterize the brains of patients with sporadic and familial Alzheimer's disease (AD) as well as elderly individuals with Down's syndrome include an excess of neurofibrillary lesions, amyloid-rich senile plaques (SPs), and the massive loss of telencephalic neurons (for recent reviews, especially to literature prior to 1990 , see Kosik, 1992; Lee and Trojanowski, 1992; Goedert, 1993; Hardy, 1993; Mullan and Crawford, 1993; Selkoe, 1993; Trojanowski et al., 1993b, 1994). The neurofibrillary lesions in AD are composed of paired helical filaments (PHFs) that are biochemically and structurally distinct from the amyloid fibrils in SPs. PHFs accumulate with straight filaments and amorphous material in perikaryal neurofibrillary tangles (NFTs), dystrophic neurites associated with SPs, and in neuropil threads (NTs) throughout the neuropil. PHFs and the straight filaments that dominate ultrastructural images of neurofibrillary lesions are formed from hyperphosphorylated adult CNS $\tau$ proteins known as $\mathrm{PHF} \tau$ or A68 (for reviews, see Goedert et al., 1993; Trojanowski et al., $1993 \mathrm{~b}, 1994)$. In contrast, the subunit proteins of amyloid fibrils are 39-43 amino acid (aa) long $\beta$-amyloid peptides $(\mathrm{A} \beta)$ derived from one or more larger, alternatively spliced amyloid precursor proteins (APPs) encoded by a gene on chromosome 21 (for detailed reviews, see Hardy, 1993; Mullan and Crawford, 1993; Selkoe, 1993). SPs are sites at which abundant accumulations of both PHFs and amyloid fibrils converge (Trojanowski et al., 
Table 1. Summary of injections and animals

\begin{tabular}{|c|c|c|c|c|c|}
\hline \multirow[b]{2}{*}{$\begin{array}{l}\text { Sample } \\
\text { injected }\end{array}$} & \multicolumn{5}{|c|}{ Postinjection survivals } \\
\hline & $1 \mathrm{hr}$ & $\begin{array}{l}1-2 \\
\text { days }\end{array}$ & $\begin{array}{l}1 \\
\text { week }\end{array}$ & $\begin{array}{l}2 / 4 \\
\text { weeks }\end{array}$ & $\begin{array}{l}8 \\
\text { weeks }\end{array}$ \\
\hline $\mathrm{PHF}_{\tau}$ & 1 & $4^{*}$ & 3 & & \\
\hline $\mathrm{PHF} \tau+\mathrm{AlCl}_{3}$ & & $4^{*}$ & 4 & $4 / 4$ & 2 \\
\hline $\mathrm{A} \beta$ & & $2 *$ & & & \\
\hline $\mathrm{A} \beta+\mathrm{AlCl}_{3}$ & & $2^{*}$ & & & \\
\hline ACT & 2 & 3 & & & \\
\hline $\mathrm{ACT}+\mathrm{AlCl}_{3}$ & & 2 & & & \\
\hline APOE & & $2^{*}$ & & & \\
\hline $\mathrm{APOE}+\mathrm{AlCl}_{3}$ & & $2^{*}$ & & & \\
\hline APOE3 & & $2^{*}$ & & & \\
\hline $\mathrm{APOE} 3+\mathrm{AlCl}_{3}$ & & $2^{*}$ & & & \\
\hline APOE4 & & $2^{*}$ & & & \\
\hline $\mathrm{APOE} 4+\mathrm{AlCl}_{3}$ & & $2^{*}$ & & & \\
\hline HSPG & & $2^{*}$ & & & \\
\hline $\mathrm{HSPG}+\mathrm{AlCl}_{3}$ & & $2^{*}$ & & & \\
\hline A $\tau$ & & $2^{*}$ & & & \\
\hline $\mathrm{A} \tau+\mathrm{AlCl}_{3}$ & & $4^{*}$ & & & \\
\hline$\Gamma \tau$ & & $4^{*}$ & & & \\
\hline $\mathrm{F}_{\tau}+\mathrm{AlCl}_{3}$ & & $2^{*}$ & 2 & & \\
\hline Syn $\tau$ & & 5 & & & \\
\hline NF-H & & 2 & & & \\
\hline $\mathrm{NF}-\mathrm{H}+\mathrm{AlCl}_{3}$ & & & 2 & $2 / 0$ & \\
\hline $\mathrm{AlCl}_{3}$ & 2 & 2 & 2 & $2 / 2$ & 2 \\
\hline
\end{tabular}

This table summarizes the injected samples and the postinjection survival times of the animals studied here. The first column lists the component that was injected, while the subsequent columns indicate the postinjection survival times. The numbers in each column indicate the number of animals studied at each time point. The 2 and 4 week survival times ( $2 / 4$ weeks) are grouped together in the same column. In at least two of the rats among the groups of animals identified by an asterisk, bilateral injections were performed in which the protein sample alone was injected into one hemisphere, and the same protein sample plus $\mathrm{AlCl}_{3}$ was injected in the opposite hemisphere. A $\tau$, adult CNS $\tau ; F \tau$, fetal CNS $\tau$; Syn $\tau$, synthetic $\tau$ peptides; UB, ubiquitin. Other abbreviations are the same as those used in the text.

1993b, 1994). Despite the presence of APP mutations in rare cases of familial AD, the abundance of NFTs correlates better with the dementia in $\mathrm{AD}$ than the density of amyloid plaques (Dickson et al., 1991; Arriagada et al., 1992; Goedert, 1993).

Although PHFs and $A \beta$ amyloid fibrils are the most distinct structural elements in NFTs and SPs, respectively, a number of other components selectively accumulate in SPs and NFTs, including ubiquitin (Mori et al., 1987; Perry et al., 1987; Shaw and Chau, 1988), $\alpha_{1}$-antichymotrypsin (ACT) (Abraham et al., 1988; Gollin et al., 1992), heparan sulfate proteoglycans (HSPGs) (Snow et al., 1988; Perlmutter et al., 1991; Perry et al., 1991), and apolipoprotein $\mathrm{E}$ (ApoE), a risk factor for sporadic and familial AD (Namba et al., 1991; Wisniewski and Frangione, 1992; Saunders et al., 1993; Schmechel et al., 1993). In addition, aluminum has been detected in NFTs and/or tangle-bearing neurons (Perl and Brody, 1980; Garruto et al., 1984; Picardo et al., 1988; Good et al., 1992; Perl and Good, 1992), as well as in some SPs (Candy et al., 1986, 1992; but see also Stern et al., 1986, and Landsberg et al., 1992, for negative studies). Despite the presence of aluminum and other proteins in NFTs and SPs, the contribution of these components to the pathogenesis of plaques and tangles is not known. However, it has been speculated that components in SPs other than $A \beta$ might contribute to the formation of amyloid plaques in AD (Snow et al., 1988,
1994; Greenberg et al., 1991; Perry, 1993; Perry et al., 1993; Shin et al., 1993; Trojanowski et al., 1993b, 1994).

To develop model systems for studying interactions between different plaque and tangle components, we showed that injections of purified PHF $\tau$ into the rodent brain induced long-lived co-deposits of $A \beta$, ubiquitin, and ACT at the injection site (Shin et al., 1993). Thus, the convergence of $\mathrm{PHF}_{\tau}$ and $\mathrm{A} \beta$ in authentic cortical SPs and NFTs (Hyman et al., 1989; Shin et al., 1989; Arai et al., 1990; Spillantini et al., 1990; Perry et al., 1992) may not reflect the stochastic outcome of separate pathological processes. Instead, it is possible that interactions of PHF $\tau$ with other tangle components, including $A \beta$ and other $A \beta$ precursor protein domains (Arai et al., 1990; Gollin et al., 1992; Perry et al., 1993), induce the aggregation of PHFs into perikaryal NFTs. Further, the release of $\mathrm{PHF}_{\tau}$ from degenerating neurons in the AD brain may contribute to the formation of SPs by interacting with $A \beta$ secreted by neural cells (Shin et al., 1993). To explore the in vivo interactions between $\mathrm{PHF} \tau, \mathrm{A} \beta$, aluminum, and other proteins in SPs and NFTs, we injected PHF $\tau$ with aluminum chloride $\left(\mathrm{AlCl}_{3}\right)$ into the rat brain and cxamined the injection sites for the presence of several proteins found in authentic SPs and NFTs. In complementary studies, we also probed interactions of $\mathrm{PHF} \tau$ with $\mathrm{AlCl}_{3}$ in situ and in vitro using $\mathrm{AD}$ brain samples.

\section{Materials and Methods}

Intracerebral injections of PHFT and other proteins with and without aluminum. Three different preparations of $\mathrm{PHF} \tau$ were purified from the brains of three different $\Lambda \mathrm{D}$ patients as described carlicr (Bramblett ct al., 1993; Shin et al., 1993) for intracerebral injection. Briefly, PHFr was purified from Sarkosyl-insoluble material and rendered water soluble by extraction with $2 \mathrm{~m}$ guanidine isothiocyanate followed by dialysis against water. Normal adult, human $\mathrm{CNS} \tau$ and fetal $\tau$ from late gestational age normal fetuses (Tohyama et al., 1991; Lee et al., 1993; Yachnis et al., 1993) were prepared as described (Bramblett et al., 1992, 1993). The normal adult and fetal brains as well as the AD brains were evaluated histopathologically and assigned to the control or AD group using consensus criteria for the diagnosis of AD (Khachaturian, 1985) as previously described (Kosik et al., 1988; Arai et al., 1990; Schmidt et al., 1990, 1991; Tohyama et al., 1991; Bramblett et al., 1992; Lee et al., 1993; Yachnis et al., 1993). Human high-molecular-weight neurofilament proteins (NF-H) were purified as described (Balin et al., 1991), and recombinant human ACT was a gencrous gift of $\mathrm{H}$. Rubin and $\mathrm{B}$. Cooperman, while purified HSPGs and human ApoE (representing a mixture of ApoE2, ApoE3, and ApoE4) were obtained from Becton Dickinson and Chemicon, respectively. Recombinant human ApoE3 and ApoE4 were obtained from Panvera. Peptides based on $A \beta_{1-42}$, as well as on several domains in CNS $\tau$ were synthesized and characterized as described (Stern et al., 1989; Lee et al., 1991; Lang et al., 1992), and samples of these peptides also were used for injection into rat brains. These synthetic $\tau$ peptides included sequences extending from aa 389 to 402 (according to the numbering system for the longest CNS $\tau$ isoform of Goedert et al., 1989) containing Ser $^{396}$ in a phosphorylated state (GAEIVYKSPVVSGD), a microtubule (MT)-binding repeat (aa 256273; VKSKIGSTENLKHQPGGG), and a carboxy-terminal $\tau$ domain containing phosphorylated $\operatorname{Ser}^{416}$ (aa 405-421; PRHLSNVSSTGSIDMVD). $\mathrm{AlCl}_{3}(20 \mathrm{~mm})$ in $0.5 \mathrm{M}$ Tris pH 6.5 was made as a stock solution and kept at $4{ }^{\circ} \mathrm{C}$. The protein samples used for injection were made up with and without added $\mathrm{AlCl}_{3}$. For co-injection of proteins with $\mathrm{AlCl}_{3}$, the protein samples were mixed at $4^{\circ} \mathrm{C}$ with the stock solution of $\mathrm{AlCl}_{3}$ (resulting in a final concentration of $10 \mathrm{mM} \mathrm{AlCl}_{3} / 0.25 \mathrm{M}$ Tris $\mathrm{pH} 6.5$ ) just prior to injection. All of these freshly prepared solutions of protein and aluminum were injected within $2 \mathrm{hr}$ after preparation. Approximately $3 \mu \mathrm{g}$ of PHF $\tau$, normal adult CNS $\tau$, fetal $\tau$, HSPGs, synthetic $\mathrm{A} \beta$, ApoE, and NF-H or $9 \mu \mathrm{g}$ of ACT all in $3 \mu \mathrm{l}$ of PBS or in $3 \mu \mathrm{l}$ of $10 \mathrm{mM} \mathrm{AlCl}_{3} / 0.25 \mathrm{M}$ Tris buffer $\mathrm{pH} 6.5$ was injected separately at each site. Further, $10 \mu \mathrm{g}$ of the synthetic $\tau_{389-402}$ peptide, $80 \mu \mathrm{g}$ of the synthetic $\tau_{256-2731}$ peptide, and $45 \mu \mathrm{g}$ of the synthetic $\tau_{405-421}$ peptide each in $3 \mu \mathrm{l}$ volume of vehicle also were injected at separate sites in different rats. 
Table 2. Summary of antibodies

\begin{tabular}{|c|c|c|c|}
\hline Antibody & Specificity & Dilution & Reference \\
\hline ALZ50 & $\tau_{2-10}$ & $1: 10$ & Wolozin et al., 1988; Goedert et al., 1991 \\
\hline T14 & $\tau_{141-178}$ & $1: 500$ & Kosik et al., 1988; Trojanowski et al., 1989 \\
\hline T46 & $\tau_{404-14}$ & $1: 500$ & Kosik et al., 1988; Trojanowski et al., 1989 \\
\hline Taul & $\tau \mathrm{npSer}^{202}$ & $1: 500 \mathrm{~d}$ & $\begin{array}{l}\text { Binder et al., 1985; Kosik et al., 1989; } \\
\text { Goedert et al., } 1993\end{array}$ \\
\hline AT8 & $\mathbf{P H F}_{\tau p \mathrm{per}^{202}}$ & $1: 500$ & Goedert et al., 1993 \\
\hline T3P* & PHF $\succ \mathrm{pSer}^{396}$ & $1: 100$ & Lee et al., 1991; Bramblett et al., 1993 \\
\hline PHF1 & $\mathrm{PHF}_{\tau} \mathrm{pSer}^{3968404}$ & $1: 2000$ & $\begin{array}{l}\text { Greenberg et al., 1992; Lang et al., 1992; } \\
\text { Bramblett et al., 1993 }\end{array}$ \\
\hline $2332^{*}$ & $A \beta_{1-42}$ & $1: 4000$ & Shin et al., 1993 \\
\hline $2134^{*}$ & $\mathrm{~A} \beta_{1-40}$ & $1: 100$ & Estus et al., 1992 \\
\hline 1510 & Ubiquitin & $1: 10000$ & Chemicon; Shaw et al., 1988 \\
\hline Anti-ACT* & $\mathrm{ACT}$ & $1: 1000$ & ICN; Abraham et al., 1988 \\
\hline Anti-ACT* & ACT & $1: 200$ & DAKO; Abraham et al., 1988 \\
\hline Anti-HSPG* & HSPG & $1: 100$ & Narindrasorasak et al., 1991 \\
\hline Anti-Apoe* & APoe & $1: 4000$ & Chemicon; Wisniewski et al., 1992 \\
\hline 1062 & APoe & 1:100 & Chemicon \\
\hline $\mathrm{RMO} 24$ & NF-H & $1: 10$ & Lee et al., 1987; Schmidt et al., 1987 \\
\hline
\end{tabular}

This table summarizes the properties of the antibodies used in this study. The name of the antibody, its specificity, the dilution of the antibody used for immunohistochemistry, and the source and/or references on the properties of these antibodies are shown in the columns from left to right, respectively. All of the antibodies are mouse MAbs except for those identified by an asterisk, which are polyclonal antibodies. ALZ50, T14, and T46 are phosphate-independent antibodies to $\tau$ that recognize fetal and adult human CNS $\tau$ as well as PHFr, but T14 does not recognize rat $\tau$ proteins. Taul recognizes normal CNS $\tau$ when $\mathrm{Ser}^{202}$ is not phosphorylated (npSer ${ }^{202}$ ), but it only binds to PHF $\tau$ after enzymatic dephosphorylation. AT8, T3P, and PHFl recognize fetal human CNS $\tau$ and PHF $\tau$, but not adult human CNS $\tau$. These MAbs bind to PHF $\tau$ when the serine residues identified in the table by the superscripts are phosphorylated (as indicated by $\left.\mathrm{pSer}^{202}, \mathrm{pSer}^{396}, \mathrm{pSer}^{396 \& 404}\right)$. The numbering system for the aa sequences of the epitopes in $\tau$ recognized by the anti- $\tau$ antibodies listed here (as indicated by the subscript numbers following the $\tau$ symbol in the second column) is based on the largest human CNS $\tau$ isoform (Goedert et al., 1989).

In control rats, the same volume of $10 \mathrm{mM} \mathrm{AlCl}_{3} / 0.25 \mathrm{M}$ Tris buffer $\mathrm{pH}$ 6.5 alone was injected.

The injections of the different proteins into the rodent CNS were performed under anesthesia using procedures similar to those described previously (Trojanowski, 1983; Shin et al., 1993). In some experiments, unilateral injections of the protein samples with or without aluminum were performed at two separate sites in the right hemisphere. In other experiments, bilateral injections of matched protein samples with and without aluminum were performed at two separate sites in the right (protein sample with aluminum) and left (protein sample without aluminum) hemispheres. Following specified postinjection survival intervals, the rats were lethally anesthetized and perfused with PBS prior to removal and immersion fixation of the brains in 70\% ethanol with 150 mm $\mathrm{NaCl}$ as described (Shin et al., 1993). The number of rats injected with different proteins as well as the postinjection survival times are summarized in Table 1. Finally, sections from a number of the rat brains $(n=36)$ that had received injections of PHFi or normal adult human CNS $\tau$ in a previous study (Shin et al., 1993) were examined further by immunohistochemistry in the experiments described here.

Light microscopic immunohistochemical studies. The ethanol-fixed rat brains were embedded in paraffin according to previously described infiltration schedules (Trojanowski et al., 1989), and serial 6- $\mu \mathrm{m}$-thick sections through the injection sites were prepared and examined by immunohistochemistry as outlined in several earlier publications (Schmidt et al., 1991; Tohyama et al., 1991; Bramblett et al., 1992. Shin et al., 1993). The panel of antibodies to normal adult and fetal CNS $\tau, \mathrm{PHF} \tau$, ubiquitin, ACT, A $\beta$, HSPGs, ApoE, and NF-H that were used in this study is summarized in Table 2.

Since some PHF $\tau$ epitopes (e.g., the amino-terminal $\tau$ epitope recognized by the T46 MAb) were not detected at all, or they were weakly immunoreactive in the aggregates that formed following injections of PHFr plus $\mathrm{AlCl}_{3}$ (see Results), we sought to determine if aluminum might bind to these epitopes and "mask" them. To do this, we treated rat brain sections at $37^{\circ} \mathrm{C}$ for $1 \mathrm{hr}$ with chelating agents including 0.1 $\mathrm{M}$ EDTA in $0.1 \mathrm{M}$ Tris $\mathrm{pH} 7.6$, or $0.1 \mathrm{M}$ desferrioxamine mesylate (DFO; Sigma) in $0.1 \mathrm{M}$ Tris $\mathrm{pH} 7.6$ prior to probing the sections with primary antibodies for immunohistochemical analysis. The rat brain sections were analyzed with and without pretreatment with chelating solutions using antibodies to $\mathrm{PHF} \tau$ as well as with antibodies to all of the other proteins examined in this study (see Table 2). In studies performed with the Taul MAb, rat brain sections were pretreated with DFO followed by enzymatic dephosphorylation of the sections using Escherichia coli alkaline phosphatase (type III-N, Sigma) as described earlier (Lee et al., 1986; Schmidt et al., 1987). Finally, absorption experiments were performed for several of the antibodies as described (Shin et al., 1991).

Immunoelectron microscopic studies of PHF injection sites. To monitor the ability of the guanidine isothiocyanate-treated, water-soluble $\mathrm{PHF} \tau$ proteins to reassemble into filaments in the rat brain, immunoclectron microscopical studies were performed as reported elsewhere (Springall et al., 1984; Balin et al., 1991; Hill et al., 1991; V. M.-Y. Lee et al., 1991; J. H. Lee et al., 1993; Shin et al., 1993). These studies were carried out on sections through $\mathrm{PHF}_{\tau}$ accumulations produced in three additional rats that received injections of PHF $\tau$ alone. These rats survived $1 \mathrm{~d}$ postinjection, and they were perfused with buffer as described above. The brains were removed immediately thereafter and small pieces of tissue from the injection sites were excised and immersion fixed in $1 \%$ glutaraldehyde $/ 2 \%$ paraformaldehyde in phosphate buffer for 4 $\mathrm{hr}$, embedded in paraffin, and then sectioned as described above. Sequential sections were probed with the antibodies to $P H F \tau$ and normal CNS $\tau$ summarized in Table 2 using the same immunohistochemical methods outlined earlier except that the peroxidase-antiperoxidase complex was replaced with an immunogold reporter system with and without silver intensification of the gold $(5 \mathrm{~nm})$ particles (Springall et al., 1984; Shin et al., 1993). Portions of the rat brain adjacent to the injection sites were excised, embedded in araldite, sectioned, and examined using a Hitachi 600 electron microscope.

Assessment of interactions between aluminum salts and AD pathology in situ. In complementary studies of the ability of aluminum salts to interact with proteins found in SPs and NFTs of the AD brain in situ, we prepared sections of hippocampus from four different AD brains and treated these sections with $10 \mathrm{mM} \mathrm{AlCl}_{3}$ in $0.25 \mathrm{M}$ Tris pH 6.5 at $37^{\circ} \mathrm{C}$ overnight prior to immunohistochemical analysis using the same antibodies described in Table 2 . The diagnostic evaluation of these $A D$ brains was performed as outlined above. 
$\operatorname{PHF} \tau$ alone

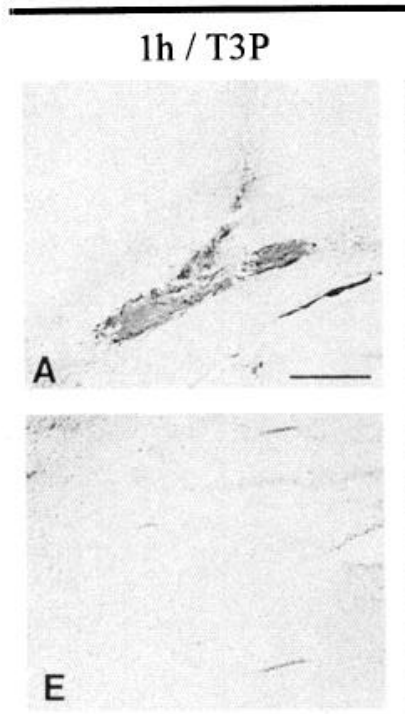

2d / T46, EDTA -
$2 \mathrm{~d} / \mathrm{T} 3 \mathrm{P}$
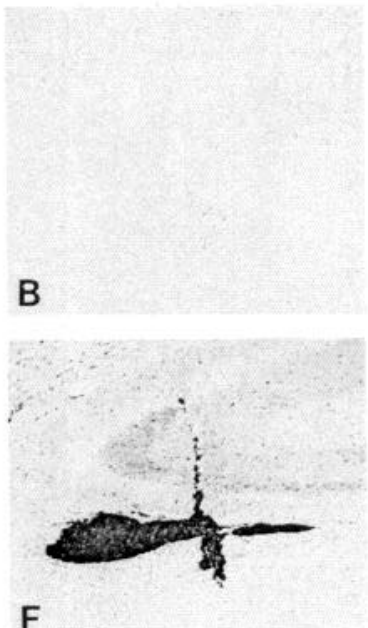

2d / T46, EDTA +
$\mathrm{PHF} \tau$ plus $\mathrm{Al}$

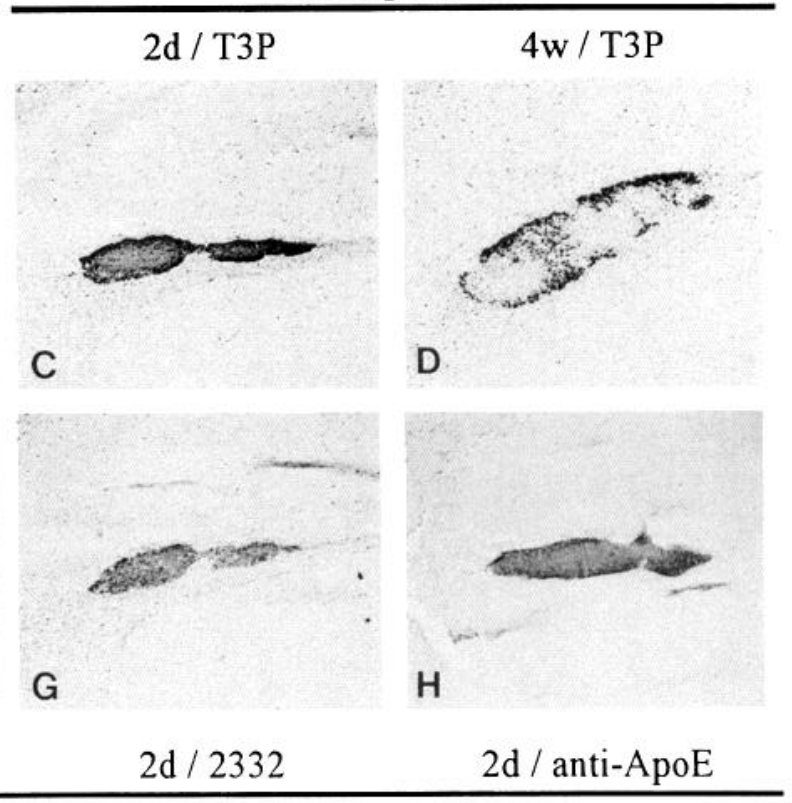

$\mathrm{PHF} \tau$ plus $\mathrm{Al}$

Figure 1. Photomicrographs of rat brains injected with $\mathrm{PHF} \tau$ alone $(A$ and $B)$ or with $\mathrm{PHF} \tau$ plus aluminum $(C-H)$ at postinjection survival times of $1 \mathrm{hr}(A), 2 \mathrm{~d}(B, C$, and $E-H)$, and 4 weeks $(D)$. Some of the sections were not pretreated with chelators $(A, B$, and $E)$, while others were pretreated with EDTA $(F)$ or DFO $(C, D, G$, and $H)$ for 1 hr prior to immunostaining with antibodies specific for PHFr $(T 3 P$ in $A-D)$, normal adult, and fetal CNS $\tau$ as well as PHF $\tau$ (T46 in $E$ and $F$ ), A $\beta$ (2332 in $G$ ), or ApoE $(H)$. The sections were counterstained with hematoxylin. All of the photomicrographs are at the same magnification. Scale bar (in $A$ ), $300 \mu \mathrm{m}$.

In vitro assessment of interactions between PHFt and aluminum. Samples from tangle-rich regions of the brains of three AD patients as well as brain samples from three neurologically and neuropathologically normal subjects were homogenized in reassembly buffer $(0.1 \mathrm{M}$ MES, $0.5 \mathrm{~mm} \mathrm{MgSO}_{4}, 1 \mathrm{~mm}$ EGTA, 2 mM dithiothreitol pH 6.8) containing $0.75 \mathrm{M} \mathrm{NaCl}$, and a cocktail of protease inhibitors $(0.5 \mathrm{M}$ phenylmethylsulfonyl fluoride and TPCK, TLCK, leupeptin, pepstatin, and soybean trypsin inhibitor, each at $1 \mathrm{gm} / \mathrm{ml}$ ) and centrifuged at $90,000 \times$ $g$ for $30 \mathrm{~min}$. The resulting supernatants were boiled for $10 \mathrm{~min}$, followed by centrifugation at $90,000 \times g$ for $60 \mathrm{~min}$, and then once again at $350,000 \times g$ for $60 \mathrm{~min}$. The final $350,000 \times g$ supernatants from the $\mathrm{AD}$ brains (which contained an aqueous-soluble fraction of $\mathrm{PHF} \tau$ as well as aqueous-soluble normal adult CNS $\tau$; see Results for further details) and from the normal brains (which only contained aqueoussoluble normal adult $\mathrm{CNS} \tau$ ) were incubated with different concentrations of $\mathrm{AlCl}_{3}$ (ranging from 0 to $1 \mathrm{~mm}$ ) in $0.25 \mathrm{M}$ Tris pH 6.5 at $37^{\circ} \mathrm{C}$ for $1 \mathrm{hr}$, and centrifuged at $90,000 \times g$ for $30 \mathrm{~min}$. The resultant supernatants and pellets were analyzed by $8.5 \%$ SDS-PAGE followed by immunoblot analysis with MAbs specific for $\mathrm{PHF}_{\tau}$ (i.e., $\mathrm{PHF} 1, \mathrm{~T} 3 \mathrm{P}$, AT8) and normal adult CNS $\tau$ (i.e., Taul) as described (Lee et al., 1991; Bramblett et al., 1992, 1993; Shin et al., 1993). The supernatants from the AD brains also were applied to nickel grids, negatively stained, and monitored by electron microscopy using a Hitachi 600 electron microscope for the presence of particulate material, straight filaments, or PHFs as outlined in previous reports (Balin et al., 1991; Lee et al., 1991).

\section{Results}

Co-injection of aluminum salts with PHFt enhances the resistance of $\mathrm{PHF \tau}$ to in vivo proteolysis

To investigate the effects of aluminum on the in vivo biological activities of $\mathrm{PHF} \tau$, we used a rodent model in which intracerebral injections of $\mathrm{PHF} \tau$ have been shown to produce clustered aggregates of $\mathrm{PHF} \tau$ that resist rapid proteolysis relative to normal adult CNS $\tau$ and fetal human (Shin et al., 1993). Accordingly, several different preparations of $\mathrm{PHF} \tau$ from different AD brains $(n=6)$ were screened for their relative resistance to in vivo proteolysis by injecting aliquots of each of the preparations into the rat CNS. We confirmed that all of these PHF $\tau$ isolates were more resistant to in vivo proteolysis than normal adult $\mathrm{CNS} \tau$, which is eliminated almost entirely within $1 \mathrm{hr}$ following intracerebral injection. However, the different $\mathrm{PHF} \tau$ preparations resisted proteolysis to varying degrees; that is, different isolates remained in the rat brain injection site for periods of time ranging from $<1$ week to $>4$ weeks. The reasons for this variation are uncertain, but similar variations have been noted earlier (Shin et al., unpublished observations), and we took advantage of this variation to assess rapidly the effects of $\mathrm{AlCl}_{3}$ on the in vivo proteolysis of $\mathrm{PHF} \tau$. Specifically, in the studies summarized below, we used one of the more rapidly proteolyzed $\mathrm{PHF} \tau$ preparations that was eliminated routinely from the injection site within 1 week.

Injections of aliquots from this preparation of $\mathrm{PHF} \tau$ without aluminum produced large aggregates of immunoreactive $\mathrm{PHF} \tau$ at $1 \mathrm{hr}$ postinjection (Fig. $1 \mathrm{~A}$ ), but most of these aggregates were removed from the injection site by $1 \mathrm{~d}$ postinjection, and only trace amounts of $\mathrm{PHF} \tau$ were detected at $2 \mathrm{~d}$ to 1 week postinjection (Fig. 1B). As described earlier (Shin et al., 1993), codeposits of $A \beta$ appeared in these aggregates at $1 \mathrm{hr}$ postinjection, and this $\mathrm{A} \beta$ immunoreactivity disappeared over the ensuing week (data not shown). When the same amount of the same $\mathrm{PHF} \tau$ preparation (i.e., $3 \mu \mathrm{g} / 3 \mu \mathrm{l}$ PBS) was co-injected with 10 mM $\mathrm{AlCl}_{3}$, aggregates of immunoreactive PHF $\tau$ also formed rapidly (within $1 \mathrm{hr}$ of injection) in the rat brain. However, these $\mathrm{PHF}_{\tau}$ aggregates persisted for up to at 8 weeks postinjection (Fig. $1 C, D$ ), after which time they were eliminated from the injection site. When sections containing the injected PHF $\tau$ plus aluminum were pretreated with metal chelators (i.e., EDTA or DFO), the pretreatment enhanced the immunodetection of the 
$\mathrm{PHF} \tau$ aggregates with antibodies that recognize both normal $\tau$ and $\mathrm{PHF} \tau$ (e.g., compare Fig. $1 E, F$ ), or only $\mathrm{PHF} \tau$ (see Fig. $1 C, D)$, and this effect was most evident at the postinjection survival times of $<1$ week.

The effect of co-injecting aluminum with $\mathrm{PHF}_{\tau}$ and the effect of pretreating sections with chelators were replicated at each postinjection survival time (i.e., two or four different rats per time point) mentioned above (data not shown). These observations also were confirmed by injecting two different PHF $\tau$ samples with and without aluminum in opposite sides of the same rat brains $(n=2)$ and examining these brains at 1 week postinjection survival times (data not shown). Thus, co-injection of aluminum with $\mathrm{PHF} \tau$ dramatically enhanced the resistance of $\mathrm{PHF} \tau$ to in vivo proteolysis, and this resulted in the prolonged persistence of PHF $\tau$ aggregates in the rat brain relative to the injections of aliquots of the same preparation of $\mathrm{PHF} \tau$ without aluminum. Further, the "unmasking" of PHF $\tau$ epitopes in sections through the injection sites containing PHF $\tau$ plus aluminum by pretreatment with chelators suggests that aluminum remained closely associated with $\mathrm{PHF} \tau$ in the injection site.

Previous studies showed that topographically separate $\mathrm{PHF}_{T}$ epitopes are eliminated from the $\mathrm{PHF}_{\tau}$ aggregates according to a distinct temporal sequence (Shin et al., 1993). For example, the carboxy-terminal $\tau$ epitope containing phosphorylated $\operatorname{Ser}^{396}$ (recognized by the PHF1 and T3P antibodies) persisted the longest (i.e., for many days to several weeks) in the rat brain, while amino-terminal $\tau$ epitopes (recognized by the ALZ50 MAb) were eliminated shortly (i.e., within a few hours) after an injection of PHF $\tau$ alone (Shin et al., 1993). In view of these observations, we characterized the temporal profile for the elimination of $\mathrm{PHF}_{\tau}$ epitopes in the injections sites containing $\mathrm{PHF}_{\tau}$ plus aluminum. These studies showed that aggregates of $\mathrm{PHF} \tau$ co-injected with aluminum retained immunoreactivity for the epitopes recognized by the PHF1, T3P, and AT8 (which recognizes the epitope containing phosphorylated $\mathrm{Ser}^{202}$ ) antibodies longer than any of the other epitopes studied here (i.e., $>4$ weeks postinjection; see Fig. $1 D$ ), while the amino-terminal epitope recognized by the ALZ50 MAb was eliminated far more rapidly (i.e., within $<2$ weeks postinjection; data not shown). However, all of the epitopes recognized by the antibodies to normal CNS $\tau$ and $\mathrm{PHF} \tau$ were eliminated much more slowly from the injection sites containing $\mathrm{PHF} \tau$ plus aluminum compared to $\mathrm{PHF} \tau$ alone (data not shown). Thus, the temporal profile for the elimination of topographically separate epitopes in PHF $\tau$ is similar for injections of $\mathrm{PHF} \tau$ with and without aluminum, but the rate at which these epitopes is eliminated appears to be far more attenuated when aluminum is co-injected with PHF $\tau$.

Previous studies also showed that $\mathrm{PHF}_{\tau}$ induced co-deposits of $\mathrm{A} \beta$, ubiquitin, and ACT at the injection sites (Shin et al., 1993). Further studies here confirmed these observations. In addition, we noted that injections of PHF $r$ alone also induced co-deposits of ApoE (data not shown). Similar co-deposits of $\mathrm{A} \beta$ (Fig. $1 G$ ), ubiquitin, ACT, and ApoE (Fig. $1 H$ ) were seen following injections of $\mathrm{PHF}_{\tau}$ with aluminum, and these codeposits remained at the injection site for prolonged periods of time (i.e., for 2 weeks postinjection) relative to injections of the same $\mathrm{PHF} \tau$ preparation without aluminum. Specifically, codeposits of $\mathrm{A} \beta, \mathrm{ACT}$, ubiquitin, and $\mathrm{ApoE}$ were induced by injections of the same preparation of $\mathrm{PHF}_{\tau}$ without aluminum, but these co-deposits remained at the injection site for $<1 \mathrm{~d}$. Thus, injections of $\mathrm{PHF}_{\tau}$ plus aluminum lead to longer-lived co-deposits of $\mathrm{A} \beta$, ubiquitin, ACT, and ApoE in the rodent brain than injections of the same preparation of $\mathrm{PHF}_{\tau}$ without aluminum.

\section{Specificity of in vivo co-deposition of $A \beta$ with $P H F_{\tau}$}

In contrast to $\mathrm{PHF} \tau$, adult and fetal human CNS $\tau$ proteins injected into rat brains were eliminated far more rapidly (i.e., within $1 \mathrm{hr}$ ) from the injection site without forming aggregates (Shin et al., 1993). Further, injections of these $\tau$ proteins as well as injections of various synthetic peptides failed to induce codeposits of $\mathrm{A} \beta$, ubiquitin, $\mathrm{ACT}$, and $\mathrm{ApoE}$ (data not shown). To determine if the proteolysis of adult and fetal human CNS $\tau$ would be influenced by co-injecting these forms of $\tau$ with aluminum, we performed additional injections of adult and fetal human CNS $\tau$ with and without aluminum as described above. Both adult (Fig. 2A) and fetal (Fig. 2C) CNS $\tau$ proteins coinjected with aluminum formed aggregates that were somewhat longer lived (e.g., as long as $2 \mathrm{~d}$ postinjection for adult $\tau$ and 1 week for fetal $\tau$ ) relative to injections of the same proteins alone in the contralateral hemisphere of the same rats (data not shown).

The aggregates of adult human $\mathrm{CNS} \tau$ plus aluminum retained only the T14 epitope (Fig. $2 A$ ) and not the epitopes recognized by the ALZ50 or T46 MAbs at 2 d postinjection. In contrast, the aggregates of human fetal $\tau$ plus aluminum retained the epitopes recognized by all these $\tau$-specific antibodies in addition to the PHF $\tau$ and fetal $\tau$-specific epitopes recognized by PHF1 (Fig. 2C), T3P, and AT8 at $2 \mathrm{~d}$ postinjection. Among the epitopes recognized by the aforementioned antibodies, those detected by ALZ50, T 14, and T46 were removed from the injection sites containing fetal $\tau$ plus aluminum by 1 week postinjection, while the epitopes detected by PHF1, T3P, and AT8 were retained in these aggregates at this postinjection time point (data not shown). Thus, aluminum conveys a greater resistance to in vivo proteolysis for the epitopes recognized by PHF1, T3P, and AT8 in both PHF $\tau$ and in fetal human CNS $\tau$. However, neither the aggregates of adult $\mathrm{CNS} \tau$ plus aluminum (Fig. $2 B$ ) nor of fetal $\tau$ plus aluminum (Fig. $2 D$ ) exhibited the ability to induce co-deposits of $\mathrm{A} \beta$. We also examined the effects of aluminum on several other proteins associated with plaques and tangles including ACT, HSPGs, and ApoE. All of the proteins injected without aluminum were rapidly cleared from the injection sites, while injections of ACT, HSPGs, or ApoE with aluminum delayed proteolysis and resulted in aggregates that were immunoreactive for either ACT (Fig. 2E), HSPGs (data not shown), or ApoE (Fig. $2 G$ ), respectively. However, none of these proteins injected with or without aluminum were able to induce co-deposits of $\mathrm{A} \beta$ (Fig. $2 F, H$ ). Further, no deposition of $A \beta$ was seen in the rat brain following injections of aluminum alone (data not shown). Thus, only injections of $\mathrm{PHF}_{\tau}$ with and without aluminum were able to induce co-deposits of $\mathrm{A} \beta$. These findings, together with data demonstrating that other proteins (e.g., NF-H) and $\tau$ peptides fail to induce co-deposits of $A \beta$ (Table 3), suggest that the ability to induce co-deposits of $A \beta$ in rat brain is a highly specific property that may be unique to $\mathrm{PHF}_{\tau}$.

\section{Several components of plaques and tangles induce co-deposits} of $A p o E$

Although injections of $\mathrm{AlCl}_{3}$ alone did not induce co-deposits of $\mathrm{ApoE}$, injections of $\mathrm{PHF} \tau$ with and without $\mathrm{AlCl}_{3}$ and injections of adult or fetal CNS $\tau$ as well as ACT, HSPGs, and NF-H with $\mathrm{AlCl}_{3}$ did induce co-deposits of ApoE. Further, injections 


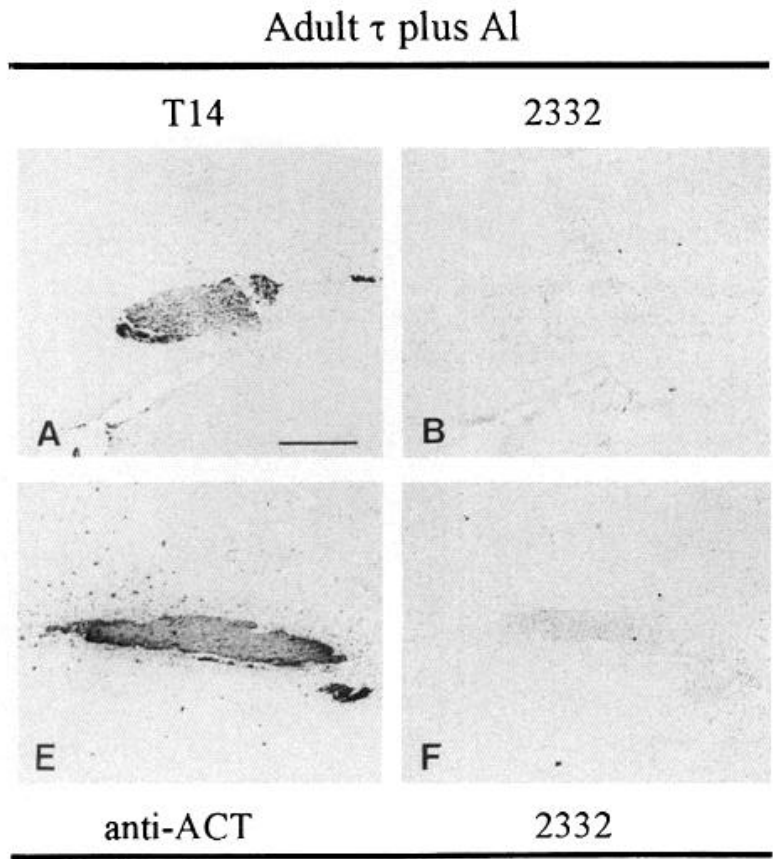

ACT plus $\mathrm{Al}$
Fetal $\tau$ plus Al

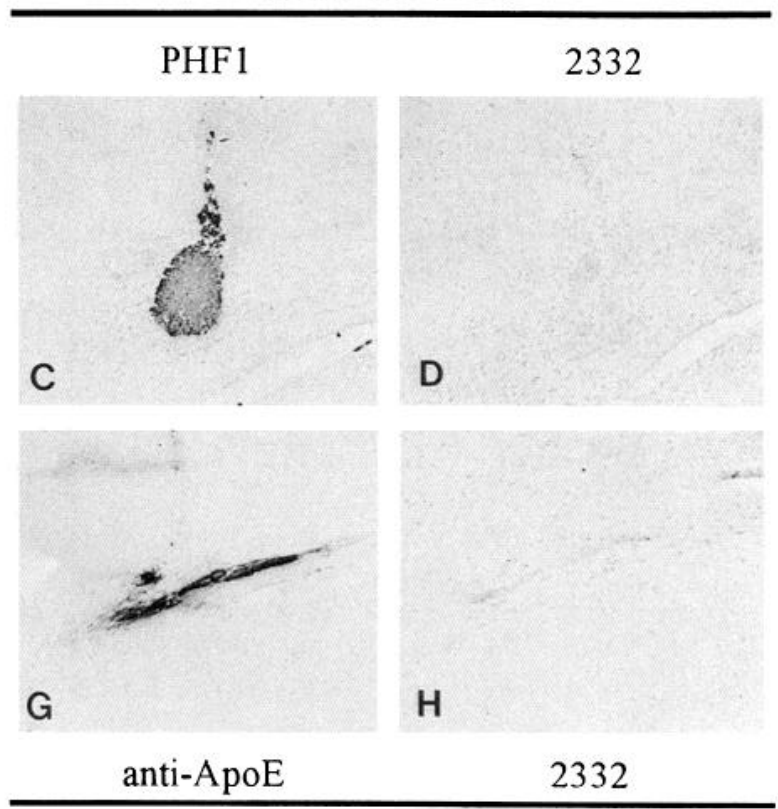

ApoE plus Al

Figure 2. Photomicrographs of rat brains injected with purified human adult CNS $\tau(A$ and $B)$, fetal CNS $\tau(C$ and $D)$, recombinant ACT $(E$ and $F$ ), and purified human $\mathrm{ApoE}\left(G\right.$ and $H$ ) at a 2 d postinjection survival time. Each of the injections also included $\mathrm{AlCl}_{3}$. All of the sections were pretreated with DFO at $37^{\circ} \mathrm{C}$ for $1 \mathrm{hr}$ followed by immunostaining with antibodies to adult and fetal CNS $\tau$ as well as PHF $\tau$ (T14 in $A$ ), PHF $\tau$ $(P H F 1$ in $C)$, ACT $(E)$, ApoE $(G)$, and $\mathrm{A} \beta(2332$ in $B, D, F$, and $H)$. The sections were counterstained with hematoxylin. All of the photomicrographs are at the same magnification. Scale bar (in $A), 300 \mu \mathrm{m}$.

\begin{tabular}{|c|c|c|c|c|c|}
\hline \multirow{2}{*}{$\begin{array}{l}\text { Sample } \\
\text { injected }\end{array}$} & \multicolumn{5}{|c|}{ Protein co-deposits } \\
\hline & $\overline{\mathrm{A} \beta}$ & Apoe & HSPG & ACT & UB \\
\hline $\mathrm{PHF} \tau$ & + & + & - & + & + \\
\hline $\mathrm{PHF} \tau+\mathrm{AlCl}_{3}$ & + & + & - & + & + \\
\hline $\mathrm{A} \beta$ & + & + & - & - & - \\
\hline $\mathrm{A} \beta+\mathrm{AlCl}_{3}$ & + & + & - & - & - \\
\hline $\mathrm{ACT}$ & - & - & - & - & - \\
\hline $\mathrm{ACT}+\mathrm{AlCl}_{3}$ & - & + & - & + & - \\
\hline APOE & - & - & - & - & - \\
\hline $\mathrm{APOE}+\mathrm{AlCl}_{3}$ & - & + & - & - & - \\
\hline APOE3 & - & - & - & - & - \\
\hline $\mathrm{APOE} 3+\mathrm{AlCl}_{3}$ & - & + & - & - & - \\
\hline APOE4 & - & - & - & - & - \\
\hline $\mathrm{APOE} 4+\mathrm{AlCl}_{3}$ & - & + & - & - & - \\
\hline HSPG & - & - & - & - & - \\
\hline $\mathrm{HSPG}+\mathrm{AlCl}_{3}$ & - & + & - & - & - \\
\hline A $\tau$ & - & - & - & - & - \\
\hline $\mathrm{A} \tau+\mathrm{AlCl}_{3}$ & - & + & - & - & - \\
\hline $\mathrm{F} \tau$ & - & - & - & - & - \\
\hline $\mathrm{F} \tau+\mathrm{AlCl}_{3}$ & - & + & - & - & - \\
\hline $\operatorname{Syn} \tau$ & - & - & - & - & - \\
\hline NF-H & - & - & - & - & - \\
\hline $\mathrm{NF}-\mathrm{H}+\mathrm{AlCl}_{3}$ & - & + & - & - & - \\
\hline $\mathrm{AlCl}_{3}$ & - & - & - & - & - \\
\hline
\end{tabular}

This table summarizes the major results of the injection data described here. The first column lists the component that was injected while the subsequent columns indicate the rodent proteins that were $(+)$ or were not $(-)$ co-deposited with the injected material at the injection sites. The abbreviations are the same as those used in the text and in Table 1. of $\mathrm{A} \beta$, with and without $\mathrm{AlCl}_{3}$, produced large $\mathrm{A} \beta$ aggregates. These injections also induced co-deposits of ApoE, but no codeposits of the other plaque or tangle components studied here (data not shown). Thus, the induction of co-deposits of ApoE is not specific to $\mathrm{PHF} \tau$ since several different plaque and tangle components were capable of inducing co-deposits of ApoE (see Table 2).

\section{Acquisition of PHFt-like immunoreactivity by rodent neurons} adjacent to aggregates of $\mathrm{PHF} \tau$ plus aluminum

Although injections of $\mathrm{PHF} \tau$ with or without $\mathrm{AlCl}_{3}$ did not induce overt neuropathological changes in the adjacent rat brain (i.e., changes over and above those seen after injections of vehicle alone or following injections of the other material described here), we did observe alterations in immunoreactivity in neurons lying within $<1000 \mu \mathrm{m}$ of the injection sites containing $\mathrm{PHF} \tau$ plus aluminum. However, these changes were only observed in sections treated with chelators prior to immunohistochemical analysis. For example, preincubation of rat brain sections with DFO for 6 or more hours revealed that only those neurons near the injection sites containing $\mathrm{PHF} \tau$ plus aluminum acquired de novo immunoreactivity for PHF1, AT8, and T3P (Fig. $3 A, B$ ). In addition, this same population of neurons also acquired Taul immunoreactivity only after the rat brain sections were pretreated with DFO and then subjected to enzymatic dephosphorylation with alkaline phosphatase (data not shown). However, using the same experimental procedures, these neurons were not immunostained with other phosphate-independent anti- $\tau$ antibodies such as ALZ50, T14 (Fig. 3C), and T46. Further, glial cells (which also contain low amounts of $\tau$ proteins; Shin et al., 1991) did not acquire $\mathrm{PHF} \tau$ immunoreactivity. Thus, 
PHF $\tau$ plus $\mathrm{Al}$

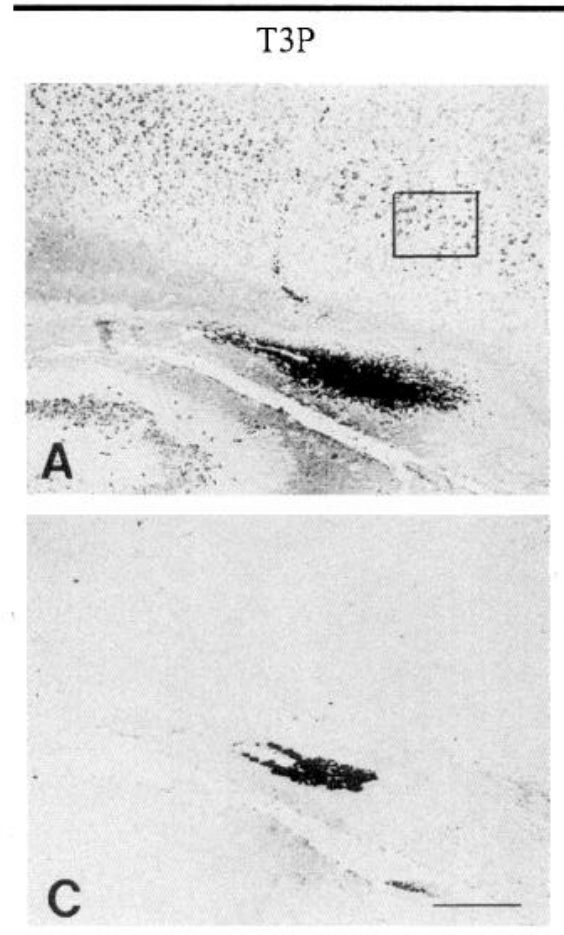

T14

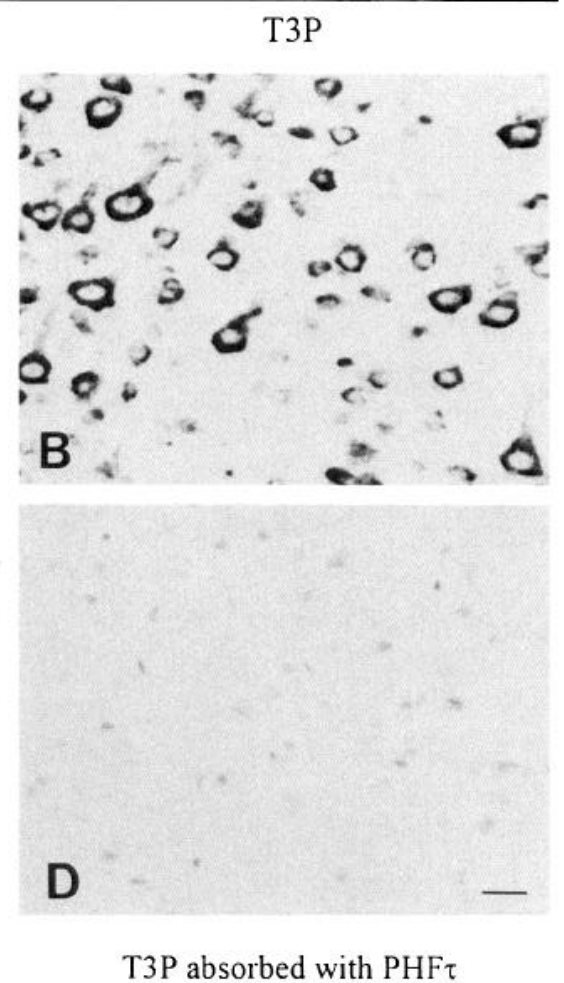

Figure 3. Photomicrographs of rat brains injected with $\mathrm{PHF} \tau$ plus aluminum at 2 weeks postinjection. The sections were pretreated with DFO at $37^{\circ} \mathrm{C}$ overnight and probed with T3P $(A, B$, and $D$ ) or T14 $(C)$. The T3P antiserum used in $D$ was absorbed with $\mathrm{PHF}_{\tau}$ (20 $\mu \mathrm{g} / \mathrm{ml}$ ), which eliminated staining of neurofibrillary lesions in sections of $\mathrm{AD}$ brain. The sections were counterstained with hematoxylin. Note that many normal-appearing rodent neurons exhibit $\operatorname{PHF} \tau(T 3 P)$ immunoreactivity near the injection site following pretreatment of the sections with DFO ( $A$ and $B$ ), and that this immunoreactivity is abolished after absorption of T3P with $\mathrm{PHF} \tau(D)$. In contrast, $\mathrm{T} 14$ stains the aggregates formed at the injection site of $\mathrm{PHF} \tau$ plus aluminum, but not any of the rodent neurons. The photomicrographs in $A$ and $C$ are at the same magnification, as are the photomicrographs in $B$ and $D$. The boxed area in $A$ is shown at higher power in $B$. Scale bars: $C, 300$ $\mu \mathrm{m}$ for $A$ and $C ; D, 20 \mu \mathrm{m}$ for $B$ and $D$. injections of $\mathrm{PHF} \tau$ with $\mathrm{AlCl}_{3}$ induced changes in the phosphorylation state of normal adult rodent $\mathrm{CNS} \tau$ in neurons near the $\mathrm{PHF} \tau$ /aluminum injection site such that several $\mathrm{PHF} \tau$-specific antibodies (i.e., PHF1, T3P, AT8) immunostained these neurons and this $\mathrm{PHF} \tau$ staining was absorbed out by incubating antibodies with $\mathrm{PHF} \tau$ (Fig. $3 D$ ). Notably, the detection of PHF $\tau$ immunoreactivity in the neurons described here required prolonged exposure to DFO. For example, similar results were not obtained following preincubations with DFO for brief periods of time (e.g., for $1 \mathrm{hr}$ ), or with the chelator EDTA. Finally, the rodent neurons that acquired de novo $\mathrm{PHF} \tau$ immunoreactivity were confined to the region adjacent to the larger aggregates of $\mathrm{PHF} \tau$ plus aluminum (i.e., within $1000 \mu \mathrm{m}$ of the injection site.

Using the same DFO pretreatment, we examined sections from the rat brains $(n=62)$ that had received intracerebral injections of the other samples described above (e.g., CNS $\tau$, ACT, ubiquitin, A $\beta$, ApoE, HSPGs, NF-H). In some of the brains ( $n=3,1 \mathrm{hr}$ and $2 \mathrm{~d}$ postinjection survival times) from the series of rats described in an earlier study (Shin et al., 1993) that received injections of $\mathrm{PHF} \tau$ alone, pretreatment with DFO revealed a small population of neurons that were immunostained by AT8, T3P, and PHF1. Further, these neurons also acquired Taul immunoreactivity following enzymatic dephosphorylation with alkaline phosphatase after initial treatment of the sections with DFO. These neurons were also confined to the injection site and were most abundant in the injection sites that contained large aggregates of $\mathrm{PHF} \tau$. In contrast, no $\mathrm{PHF} \tau$ immunoreactivity was induced in rat neurons surrounding injection sites containing normal adult or fetal human CNS $\tau$, ACT, HSPGs, ApoE, or NF-H with and without $\mathrm{AlCl}_{3}$, and injections of $\mathrm{AlCl} ; 3$ alone did not produce similar changes in protein immunoreactivity (data not shown).

Taken together, the observations from all of the rats studied here are most compatible with one of the following possibilities: (1) $\mathrm{PHF} \tau$ injected with aluminum is capable of inducing the hyperphosphorylation of $\mathrm{Ser}^{202}, \mathrm{Ser}^{396}$, and $\mathrm{Ser}^{404}$ in rodent CNS $\tau$ proteins by activating kinases and/or blocking phosphatases; (2) $\mathrm{PHF} \tau$ (or proteolytic fragments thereof) is internalized with the co-injected aluminum by rat neurons and that the $\mathrm{PHF} \tau$ epitopes recognized by T3P, AT8, and PHF1 are protected from degradation within neurons by aluminum.

\section{Immunoelectron microscopic studies of PHFt injection sites}

Previous studies showed that $\mathrm{PHF} \tau$ proteins do not reassemble into PHFs or straight filaments in vitro following treatment with guanidine isothiocyanate, which is used to render these proteins water soluble for MT-binding studies (Bramblett et al., 1993) or for injection into the rat brain (Shin et al., 1993). Although rare T3P-positive straight filaments $(\sim 10-25 \mathrm{~nm}$ in diameter) were observed in one of two rats that survived $1 \mathrm{~d}$ following injections of PHF $\tau$ alone (Shin et al., 1993), examination of three additional rats injected with $\mathrm{PHF} \tau$ without $\mathrm{AlCl}_{3}$ did not reveal $\mathrm{PHF} \tau$-immunoreactive filaments (data not shown). Additional in vitro electron microscopic studies of the guanidine isothiocyanate-treated $\mathrm{PHF} \tau$ preparations prior to injection into the rat brain also failed to reveal reassembled PHFs. Hence, the ability of $\mathrm{PHF} \tau$ proteins to reassemble into filaments in the rat brain following guanidine isothiocyanate treatment appears to be very limited under the experimental conditions described here. Finally, recent in vitro studies indicate that aluminum does not induce $\tau$ to form PHFs (Scott et al., 1993).

\section{Exogenous aluminum salts specifically interact with $P H F \tau$ in AD neurofibrillary lesions}

To determine if aluminum salts interact with proteins in AD lesions in situ, we incubated 6- $\mu$ m-thick paraffin sections of the 
Figure 4. The selective elimination of $\mathrm{PHF} \tau$ immunoreactivity from sections of the AD hippocampus by pretreating sections with aluminum. Closely adjacent sections of hippocampus from the $\mathrm{AD}$ brain were preincubated with control buffer $(A$ and $C)$ or with buffer containing $10 \mathrm{~mm} \mathrm{AlCl}_{3}(B$ and $D)$ at $37^{\circ} \mathrm{C}$ overnight followed by immunostaining with antibodies to $\mathrm{PHF}_{\tau}$ (AT8 in $A$ and $B)$ or to $A \beta(2332$ in $C$ and $D)$. The sections were counterstained with hematoxylin. The asterisk in $A$ and $B$ and the star in $C$ and $D$ indicate the same blood vessel in each pair of photomicrographs, respectively. All of the photomicrographs are at the same magnification. Scale bar (in $A$ ), $100 \mu \mathrm{m}$.
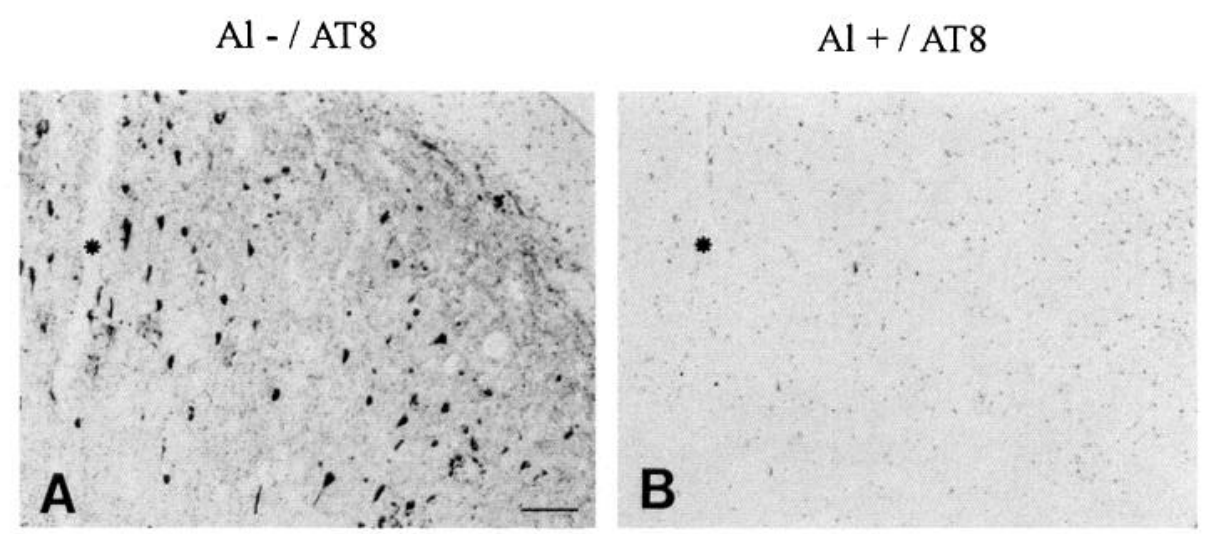

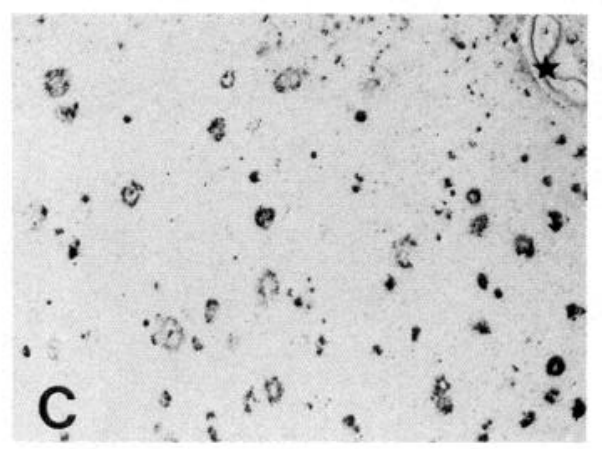

$\mathrm{Al}-/ 2332$

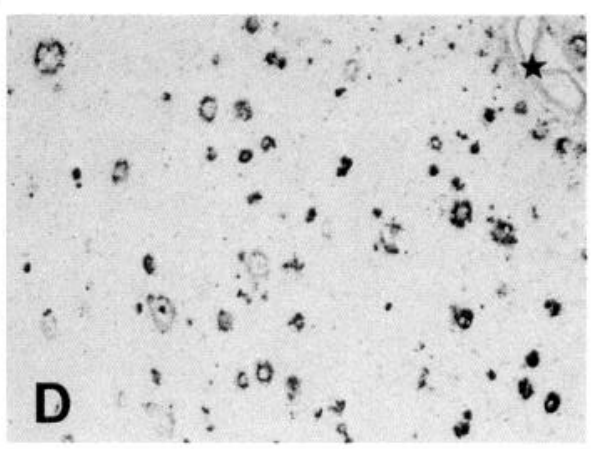

$\mathrm{Al}+/ 2332$
AD hippocampus brain with $\mathrm{AlCl}_{3}$ prior to probing these sections with antibodies to defined plaque and tangle components using immunohistochemistry. Remarkably, preincubation of AD hippocampal sections with $\mathrm{AlCl}_{3}$ dramatically reduced or completely abolished the PHF $\tau$ immunoreactivity of NFTs, NTs, and dystrophic plaque neurites in studies conducted with the phosphate-dependent antibodies PHF1, T3P, and AT8 (compare Fig. $4 A, B$ ), whereas the immunostaining obtained with phosphate-independent anti- $\tau$ antibodies (i.e., ALZ50, T14, and T46) was unchanged or very mildly diminished (data not shown). Further, preincubation of sections with $\mathrm{AlCl}_{3}$ did not affect the immunostaining of $\mathrm{AD}$ lesions using antibodies to $\mathrm{A} \beta$, ubiquitin, ACT, ApoE, and HSPGs (see Fig. $4 C, D$ for data on $\mathrm{A} \beta$ ). Thus, the ability of exogenous aluminum salts to "mask" the immunoreactivity of proteins in amyloid and neurofibrillary lesions in sections of the AD hippocampus appears to be limited to $\mathrm{PHF} \tau$ proteins, and especially those $\mathrm{PHF} \tau$ epitopes that contain phosphorylated serine residues (i.e., $\mathrm{Ser}^{202}, \mathrm{Ser}^{396}$, and $\mathrm{Ser}^{404}$ ). Indeed, neither the distribution nor the intensity of the immunoreactivity of several other proteins in amyloid or neurofibrillary lesions was affected by pretreating AD hippocampal sections with aluminum salts. Since aluminum binds avidly to phosphoproteins, and the conformation of a protein may be modified when aluminum binds to it (Webb et al., 1973; Siegel et al., 1983; Birchall and Chappell, 1988), the observations described here may be due to aluminum-induced conformational changes that result from the binding of aluminum to specific domains (i.e., the PHF1, T3P, and AT8 epitopes) in PHF $\tau$ that contain phosphorylated residues. Taken together with previous data demonstrating increased levels of aluminum in NFTs (Perl and Brody, 1980; Garruto et al., 1984; Picardo et al., 1988; Good et al., 1992; Perl and Good, 1992), the present findings imply that the aluminum in NFTs may bind selectively to $\mathrm{PHF} \tau$, and that these interactions between aluminum and $\mathrm{PHF} \tau$ may alter the physical/chemical properties of these proteins.

\section{Aluminum salts induce aggregation of $P H F \tau$ proteins in vitro and alter their electrophoretic properties}

Immunoblot analysis (using PHF1, T3P, AT8, and Taul) of the $350,000 \times g$ supernatant derived from the AD brain extracts demonstrated the presence of small amounts of $\mathrm{PHF} \tau$ proteins (i.e., immunobands with an $M_{r}$ of $60-70 \mathrm{kDa}$ that were reactive with PHF1, T3P, and AT8, but negative for Tau1) as well as some normal adult $\mathrm{CNS} \tau$ proteins (i.e., the more rapidly migrating immunobands that were labeled by Taul, but not by PHF1, T3P, or AT8) as seen in Figure 5 (compare lanes 3 in Fig. $5 A, B)$. When negatively stained preparations of this fraction were examined by electron microscopy, some particulate material was noted, but there were no PHFs or straight filaments. These findings are consistent with the notion that a small amount of heat stable $\mathrm{PHF} \tau$ may exist in a nonfilamentous and aqueoussoluble form in these high-speed supernatants. In contrast to the material from the AD brains, the $350,000 \times g$ supernatant from the normal control brain extracts only contained normal adult CNS $\tau$ proteins that were indistinguishable from the normal CNS $\tau$ proteins in the AD brain (data not shown). Since small amounts of $\mathrm{PHF} \tau$ remained in the final $350,000 \times g$ supernatant with normal adult $\mathrm{CNS} \tau$, we deliberately selected these preparations for the in vitro analyses to assess the differential effects of $\mathrm{AlCl}_{3}$ on PHF $\tau$ and normal adult CNS $\tau$ in the same AD brain extracts under identical conditions.

Following incubations of the AD and control brain 350,000 $\times g$ supernatants with varying concentrations of $\mathrm{AlCl}_{3}$ (i.e., $0.1-$ $1.0 \mathrm{~mm}$ ) at $37^{\circ} \mathrm{C}$ for $1 \mathrm{hr}$, the solubility properties and electro- 
A. PHF1

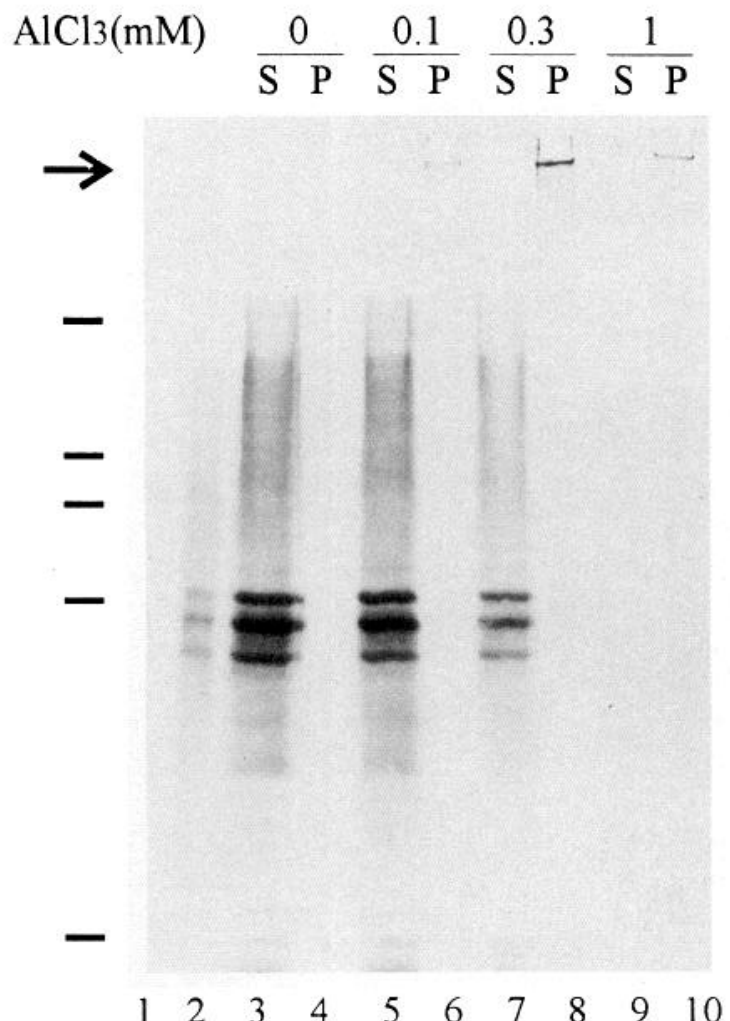

B. Tau1

$$
\frac{0}{S \text { P S P }} \frac{0.1}{\text { S P }} \frac{1}{S \text { P }}
$$

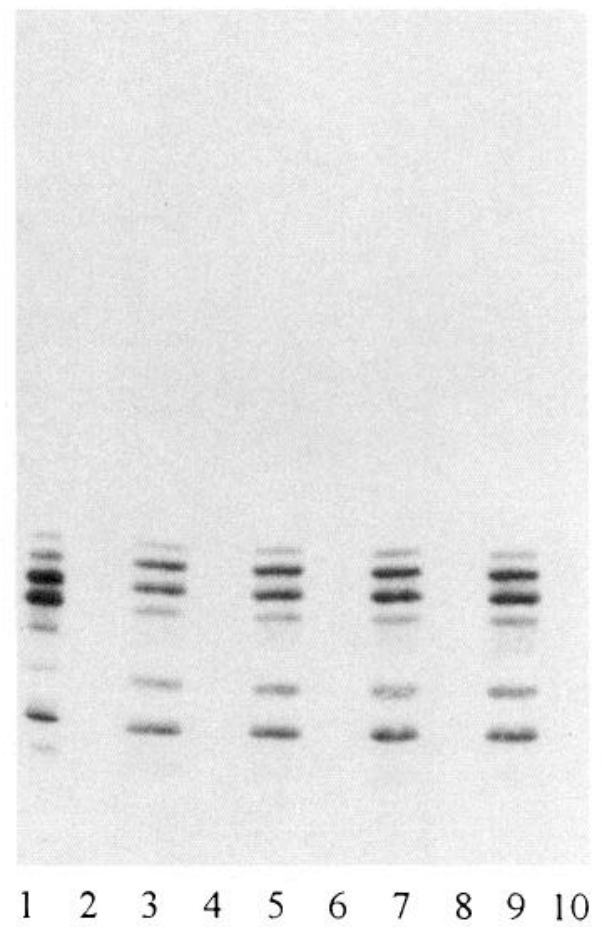

Figure 5. Immunoblot analysis of the effects of aluminum on PHF $\tau$ versus adult human CNS $\tau$. Aliquots of the same $350,000 \times g$ supernatant prepared from an AD brain were incubated with $0 \mathrm{~mm}$ (lanes 3 and 4), $0.1 \mathrm{~mm}$ (lanes 5 and 6 ), $0.3 \mathrm{~mm}$ (lanes 7 and 8 ), 1.0 mM (lanes 9 and 10) $\mathrm{AlCl}_{3}$ at $37^{\circ} \mathrm{C}$ for $1 \mathrm{hr}$ followed by centrifugation at $90,000 \times \mathrm{g}$ for $30 \mathrm{~min}$. For each of these samples, the resulting supernatants (lanes 3,5 , 7, and 9 ) and pellets (lanes 4, 6, 8, and 10) were analyzed using 8.5\% SDS-PAGE and immunoblots. After transfer to nitrocellulose paper, the gel replicas were probed with PHF1 $(A)$ and Taul $(B)$. As controls, lanes 1 and 2 were loaded with a sample of normal adult CNS $\tau$ purified from a control brain (lane 1 in $A$ and $B$ ) as well as a sample of PHF $\tau$ purified from another AD brain (lane 2 in $A$ and $B$ ). The arrow at the top of the Western blot in $A$ indicates the position of the top of the stacking gel. The position of $M_{r}$ markers is indicated at the left of $A$. From top to bottom, these markers correspond to $205,116,97,66$, and $45 \mathrm{kDa}$, respectively.

phoretic mobility of the $\mathrm{PHF} \tau$ proteins in the AD brain supernatants were dramatically altered (Fig. $5 A$ ), while no changes were noted in the normal adult CNS $\tau$ proteins in the AD (Fig. $5 B$ ) and control brain samples (data not shown). For example, increasing concentrations of $\mathrm{AlCl}_{3}$ reduced the abundance of $\mathrm{PHF}$ 1-positive $\mathrm{PHF} \tau$ bands and induced the accumulation of PHF1-positive material at the top of the stacking gel. This SDSinsoluble material presumably represents aluminum-induced aggregates of $\mathrm{PHF} \tau$ that did not enter the stacking gel (Fig. 5A), and similar effects of other aluminum salts on PHF $\tau$ were described recently (Scott et al., 1993). Indeed, at the higher concentrations of aluminum (i.e., at $1 \mathrm{~mm} \mathrm{AlCl}_{3}$ ), almost no immunoreactive $\mathrm{PHF} \tau$ was present in the Western blots (see lanes 9 and 10 in Fig. $5 A$ ). In contrast, the normal adult $\mathrm{CNS} \tau$ proteins that were present with $\mathrm{PHF} \tau$ in the same AD brain supernatant fraction were unaffected by the same incubations with increasing concentrations of $\mathrm{AlCl}_{3}$ (Fig. $5 B$ ). Similarly, no changes were observed in the normal adult CNS $\tau$ proteins that were present in the $350,000 \times g$ supernatant obtained from the control brains (data not shown). Thus, although aluminum may interact with a number of different polypeptides including normal proteins under some conditions (Scott et al., 1993), we show here that aluminum preferentially interacts with and modifies specific physical and chemical properties of $\mathrm{PHF} \tau$ relative to adult human CNS $\tau$ under the conditions described here.

\section{Discussion}

The data described here significantly extend previous findings on the induction of co-deposits of several different plaque and tangle components (i.e., $\mathrm{A} \beta$, ubiquitin, $\mathrm{ACT}$ ) in the rodent brain by intracerebral injections of $\mathrm{PHF} \tau$ (Shin et al., 1993). The unique ability of $\mathrm{PHF} \tau$ to induce co-deposits of $\mathrm{A} \beta$, ubiquitin, and ACT in the rodent brain was reinforced here by showing that injections of several other plaque and tangle components (i.e., ACT, ApoE, and HSPGs) with and without aluminum failed to induce similar co-deposits. More importantly, we demonstrated that aluminum salts modulate the properties of injected $\mathrm{PHF} \tau$ proteins in the rat brain by retarding the proteolysis of these proteins at the injection site, thereby extending the longevity of the co-deposits of $\mathrm{A} \beta, \mathrm{ACT}$, and ubiquitin. Furthermore, the complementary in situ and in vitro studies have partially characterized the more salient aspects of the interactions of $\mathrm{AlCl}_{3}$ with $\mathrm{PHF} \tau$ that might account for the in vivo observations reported here. Specifically, the in situ and in vitro data suggest that the effects of $\mathrm{AlCl}_{3}$ on the physical and chemical properties of $\mathrm{PHF} \tau$ injected into the rat brain may be due to 


\section{HYPOTHETICAL SEQUENCE OF EVENTS LEADING TO PHF $\tau$ AGGREGATION WITH OTHER COMPONENTS IN AD NFTs AND SPs}
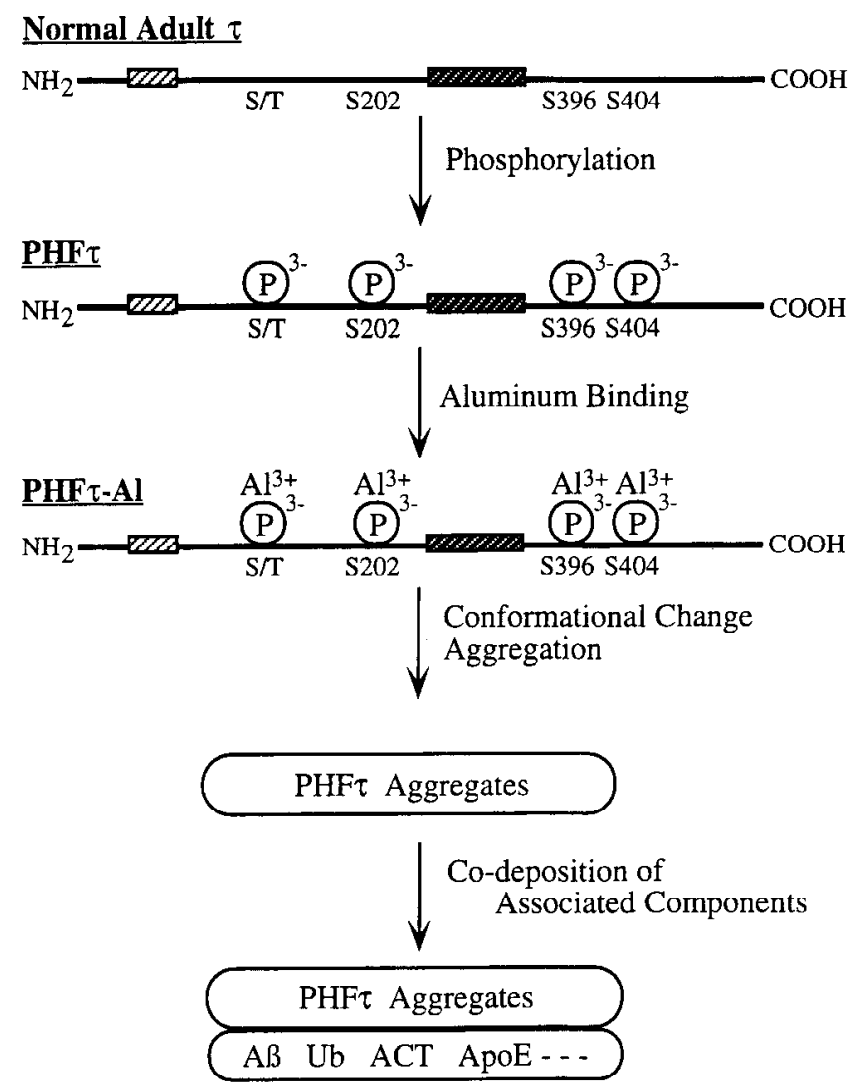

Figure 6. How interactions between aluminum and PHF $\tau$ could represent steps in a hypothetical sequence of events that lead to the aggregation of PHFs in NFTs and SPs. Normal CNS $\tau$ is shown in the top portion of the schematic oriented with the amino terminus $\left(\mathrm{NH}_{2}\right)$ on the left and the carboxy terminus (COOIn) on the right. The aminoterminal (light cross-hatching) and MT-binding (dark cross-hatching) inserts are shown for this 441 -aa-long form of adult CNS $\tau$. Also shown are unidentified Ser/Thr $(S / T)$ motifs and representative Ser residues (i.e., $\mathrm{Ser}^{202}, \mathrm{Ser}^{396}$, and $\mathrm{Ser}^{404}$ ) that are known to be phosphorylated (circled $P$ with a 3 - superscript) in $\mathrm{PHF}_{\tau}$, which is shown below normal CNS $\tau$. The interaction of aluminum $\left(A l^{3+}\right)$ with $\operatorname{PHF} \tau(P H F \tau-A l)$ also is depicted in the schematic. The figure shows the conversion of CNS $\tau$ into $\mathrm{PHF} \tau$ by phosphorylation and the interaction of aluminum with $\mathrm{PHF}_{\tau}$, which leads to the increased resistance of PHF $\tau$ to proteolysis, its aggregation, and association with other proteins found in SPs and NFTs such as $A \beta$, ubiquitin (Ub), $A C T$, and $A p o E$ (lower portion of the schematic).

the ability of aluminum to bind selectively to domains in PHF $\tau$ that contain phosphorylated Ser or other residues, and this in turn might lead to the aggregation, diminished solubility, and delayed proteolysis of PHF $\tau$ in vivo (see schematic summary of these events in Fig. 6). The results described here are all the more remarkable, considering the fact that $\mathrm{AlCl}_{3}$ may not remain soluble at the $\mathrm{pH}$ of the vehicle $(\mathrm{pH} 6.5)$ used here, or at the physiological pH in the brain (Martin, 1992).

Although the role of aluminum in $\mathrm{AD}$ is uncertain (McLachlan et al., 1992; Perl and Good, 1992; Marksbery and Ehmann, 1994), circumstantial cvidence implicates aluminum in the pathogenesis of AD. This evidence includes (1) the detection of aluminum in some $\mathrm{AD}$ lesions as well as in tangle-bearing neurons (Perl and Brody, 1980; Garruto et al., 1984; Good et al., 1992); (2) epidemiological data linking aluminum levels in the water supply to the prevalence of AD (Martyn et al., 1989); (3) the modest therapeutic response to treatment of AD patients with DFO (Crapper-McLachlan ct al., 1991); (4) the ability of aluminum to induce phosphorylation of normal $\tau$ (Yamamoto et al., 1990; Guy et al., 1991; Abdel-Ghany et al., 1993) and a small number of other CNS proteins (Johnson and Jope, 1988; Johnson et al., 1990); and (5) the ability of aluminum to promote aggregation of $A \beta$ (Mantyh et al., 1993). Although aluminum does not induce normal CNS $\tau$ to form PHF $\tau$-like structures in vitro (Scott et al., 1993), we have demonstrated here that aluminum interacts with $\mathrm{PHF}_{\tau}$ and alters its physical and chemical properties. We also show that aluminum enhances the longevity of PHF $\tau$ in vivo and extends the longevity of $\mathrm{PHF} \tau$-induced codeposits of $\mathrm{A} \beta$ and plaque and tangle-associated proteins. Further, it also induces rodent neurons to acquire PHFr-like immunoreactivity. The evidence here that aluminum enhances the resistance of PHFr to in vivo proteolysis is compatible with the notion that aluminum may play a role in the pathogenesis of AD. If this indeed is the case, then our data imply that aluminum may serve as a cofactor in the formation of $\mathrm{PHF}_{\tau}$-rich neurofibrillary lesions as well as in the convergence of $\mathrm{PHF} \tau, \mathrm{A} \beta$, ubiquitin, ACT, and ApoE in amyloid-rich SPs.

One of the key events in the formation of $\mathrm{PHF}_{\tau}$ involves the hyperphosphorylation of normal adult CNS $\tau$, which renders these abnormal proteins incapable of binding to microtubules (Bramblett et al., 1993). Recently, it was shown that a PHFrlike species could be generated from normal adult recombinant human CNS $\tau$ in vitro using purified mitogen-activated protein kinases, glycogen synthase kinase-3, and proline-directed kinases (Drewes et al., 1992; Goedert et al., 1992; Hanger et al., 1992; Mandelkow et al., 1992; Vulliet et al., 1992) as well as by specific inhibitors of protein phosphatase $2 \mathrm{~A}_{1}$ and protein phosphatase 2B (Goedert et al., 1992; Harris et al., 1993). Whether or not aluminum plays a direct role in the generation of $\mathrm{PHF}_{\tau}$ is unknown, but aluminum has been shown to modulate the phosphorylation and dephosphorylation of $\tau$ proteins (Guy et al., 1991; Abdel-Ghany et al., 1993). Further, an inhibitory effect of aluminum on the dephosphorylation of $\tau$ mediated by protein phosphatase $2 \mathrm{~A}$ has been documented although there was no indication that aluminum was directly bound to this enzyme (Yamamoto et al. 1990). Additionally, aluminum is able to modify the conformation of proteins by inducing $\beta$-pleated sheet structure (Hollosi et al., 1992). Although neurons near the injection sites of $\mathrm{PHF}_{\tau}$ plus aluminum acquired $\mathrm{PHF}_{\tau}$-like epitopes (as recognized by AT8, T3P, and PHF1 antibodies as well as by the Tau 1 MAb following alkaline phosphatase treatment), the mechanism whereby this occurs is not clear, and previous studies of injections of aluminum alone into the brains of experimental animals produced accumulations of neurofilaments but no PHFr inclusions (Selkoe et al., 1979; Munoz-Garcia et al., 1986; Troncoso et al., 1986; Wisniewski et al., 1986; Kowall et al., 1989). Further, patients with elevated aluminum levels due to dialysis develop an encephalopathy, but this is not due to the accumulation of AD-like pathology (Candy et al., 1992), and the accidental implantation of metallic aluminum in the human brain has not led to the induction of $A D$ lesions (Foncin and El Hachimi, 1986). Nonetheless, the reproducible effect of injections of PHF $\tau$ plus aluminum on $\tau$ immunoreactivity in rodent neurons does suggest that aluminum in combination with PHF $\tau$ may modulate the phosphorylation state of CNS $\tau$ in vivo. However, further studies are needed to 
determine if and how aluminum modulates the phosphorylation state of $\tau$ in the rodent and human CNS.

These and other questions concerning the pathogenesis of plaques, tangles, neuron loss, and other molecular lesions in the $\mathrm{AD}$ brain have yet to be fully answered even though there has been dramatic progress in the past decade toward elucidating the molecular composition of plaques and tangles (Goedert, 1993; Selkoe, 1993; Trojanowski et al., 1993b, 1994). In the absence of a complete animal model of the authentic human AD phenotype, we expect that experimental paradigms such as the one described here should prove effective in research efforts to arrive at a closer understanding of the mechanisms leading to the formation of complex $\mathrm{AD}$ lesions such as plaques and tangles.

\section{References}

Abdel-Ghany M, El-Sebae AK, Shalloway D (1993) Aluminum-induced nonenzymatic phospho-incorporation into human tau and other proteins. J Biol Chem 268:11976-11981.

Abraham CR, Selkoe DJ, Potter H (1987) Immunochemical identification of the serine protease inhibitor $\alpha_{1}$-antichymotrypsin in the brain amyloid deposits of Alzheimer's disease. Cell 52:487-501.

Arai H, Lee VM-Y, Otvos L, Greenberg B, Lowery DE, Sharma SK, Schmidt ML, Trojanowski JQ (1990) Defined neurofilament, $\tau$, and $\beta$-amyloid precursor protein epitopes distinguish Alzheimer from nonAlzheimer senile plaques. Proc Natl Acad Sci USA 87:2249-2253.

Arriagada PA, Growdon JH, Hedley-White ET, Hyman BT (1992) Neuro-fibrillary tangles but not senile plaques parallel duration and severity of Alzheimer's disease. Neurology 42:631-639.

Balin BJ, Clark EA, Trojanowski JQ, Lee VM-Y (1991) Neurofilament reassembly in vitro: biochemical, morphological and immuno-electron microscopic studies employing monoclonal antibodies to defined epitopes. Brain Res 556:181-195.

Binder LI, Frankfurter A, Rebhun LI (1985) The distribution of tau in the mammalian central nervous system. J Cell Biol 101:13711378.

Birchall JD, Chappell JS (1988) Aluminum, chemical physiology, and Alzheimer's disease. Lancet ii:1008-1010.

Bramblett GT, Trojanowski JQ, Lee VM-Y (1992) Regions with abundant neurofibrillary pathology in human brain exhibit a selective reduction in levels of binding-competent tau and accumulation of abnormal tau-isoforms (A68 proteins). Lab Invest 66:212-222.

Bramblett GT, Goedert M, Jakes R, Merrick SE, Trojanowski JQ, Lee VM-Y (1993) Abnormal tau phosphorylation at $\mathrm{Ser}^{396}$ in Alzheimer's disease recapitulates development and contributes to reduced microtubule binding. Neuron 10:1089-1099.

Candy JM, Oakley AE, Klinowski J, Carpenter TA, Perry RM, Arack JR, Perry EK, Blessed G, Fairbairn A, Edwardson JA (1986) Aluminosilicates and senile plaque formation in Alzheimer's disease. I ancet i:354-357

Candy JM, McArthur FK, Oakley AE, Taylor GA, Chen CPL-H, Mountfort SA, Thompson JE, Chalker PR, Bishop HE, Beyreuther K, Perry G, Ward MK, Martyn CN, Edwardson JA (1992) Aluminum accumulation in relation to senile plaque and neurofibrillary tangle formation in the brains of patients with renal failure. J Neurol Sci 107:210-218.

Crapper McLachlan DR, Dalton AJ, Kruck TPA, Bell MY, Smith WL, Kalow W, Andrews DF (1991) Intramuscular desferrioxamine in patients with Alzheimer's disease. Lancet 337:1304-1308.

Dickson DW, Crystal HA, Mattiace LA, Masur DM, Blau AD, Davies P, Yen S-H, Aronson M (1991) Identification of normal and pathological aging in prospectively studied nondemented elderly humans. Neurobiol Aging 13:179-189.

Drewes $G$, I ichtenherg-Kragg B, Doring F, Mandelkow EM, Bienart J, Doree M, Mandelkow E (1992) Mitogen activated protein (MAP) kinase transform tau protein into an Alzheimer-like state. EMBO J $11: 2131-2138$

Estus S, Golde TE, Kunishita T, Blades D, Lowery D, Eisen M, Usiak M, Qu X, Tabira T, Greenberg B, Younkin SG (1992) Potentially amyloidogenic, carboxy-terminal derivatives of the amyloid protein precursor. Science 255:726-728.
Foncin JF, El Hachimi KH (1986) Neurofibrillary degeneration in Alzheimer's disease: a discussion with a contribution to aluminum pathology in man. In: Current problems in senile-dementias, No 1 (Bes A, Cahn J, Cahn R, Hoyer S, Marc-Vergnes JP, Wisniewski HM, eds), pp 202-210. London: Liberty Eurotext.

Garruto RM, Fukatsu R, Yanagihara R, Gajdusek DC, Hook G, Fiori $C E$ (1984) Imaging of calcium and aluminum in neurofibrillary tangle-bearing neurons in parkinsonism-dementia of Guam. Proc Natl Acad Sci USA 81:1875-1879.

Goedert M (1993) Tau protein and the neurofibrillary pathology of Alzheimer's disease. Trends Neurosci 16:460-465.

Goedert M, Spillantini MG, Jakes R, Rutherford D, Crowther RA (1989) Multiple isoforms of human microtubule-associated protein tau: sequences and localization in neurofibrillary tangles of Alzheimer's disease. Neuron 3:519-526.

Goedert M, Spillantini MG, Jakes R (1991) Localization of the Alz50 epitope in recombinant human microtubule-associated protein tau. Neurosci Lett 126:149-154.

Goedert M, Cohen ES, Jakes R, Cohen P (1992) p42 MAP kinase phosphorylation sites in microtubule-associated protein tau are dephosphorylated by protein phosphatase $2 A_{1}$. FEBS Lett 312:95-99.

Goedert M, Jakes R, Crowther RA, Six J, Lubke U, Vandermeeren M, Cras P, Trojanowski JQ, Lee VM-Y (1993) The abnormal phosphorylation of tau proteins at Ser-202 in Alzheimer disease recapitulates phosphorylation during development. Proc Natl Acad Sci USA 90:5066-5070.

Gollin PA, Kalaria RN, Eikelenboom P, Rozemuller A, Perry G (1992) $\alpha_{1}$-antitrypsin and $\alpha_{1}$-antichymotrypsin are in the lesions of Alzheimer's disease. Neuroreport 3:201-203.

Good PF, Perl DP, Bierer LM, Schmeidler J (1992) Selective accumulation of aluminum and iron in the neurofibrillary tangles of $\mathrm{Al}$ zheimer's disease: a laser microprobe (LAMMA) study. Ann Neurol 31:286-292.

Greenberg SG, Davies P, Schein JD, Binder LI (1992) Hydrofluoric acid-treated $\tau$ PHF proteins display the same biochemical properties as normal $\tau$. J Biol Chem 267:564-569.

Greenberg BD, Keszdy FJ, Kisilevsky R (1991) Amyloidosis as a therapeutic target in Alzheimer's disease. Ann Rep Med Chem 26: 229-238.

Guy SP, Jones D, Mann DMA, Itzhaki RF (1991) Human neuroblastoma cells treated with aluminum express an epitope associated with Alzheimer's disease neurofibrillary tangles. Neurosci Lett 121: 166-168.

Hanger DP, Hughes K, Wlldgett JR, Brion JP, Anderton BH (1992) Glycogen synthase kinase- 3 induces Alzheimer's disease-like phosphorylation of tau: generation of paired helical filament epitopes and neuronal localization of the kinase. Neurosci Lett 147:58-62.

Hardy J (1993) Genetic mistakes point the way for Alzheimer's disease. J NIH Res 5:46-49.

Harris KA, Oyler GA, Doolittle GM, Vincent I, Lehman RAW, Kincaid RL, Billingsley ML (1993) Okadaic acid induces hyperphosphorylated forms of tau protein in human brain slices. Ann Neurol 33:7787.

Hill WD, Lee VM-Y, Hurtig HI, Murray JM, Trojanowski JQ (1991) Epitopes located in spatially separate domains of each neurofilament subunit are present in Parkinson's disease Lewy bodies. J Comp Neurol 109:150-160.

Hollosi M, Urge L, Perczel A, Kajtar J, Teplan I, Otvos L Jr, Fasman GD (1992) Metal ion-induced conformational changes of phosphorylated fragments of human neurofilament (NF-M) protein. J Mol Biol 223:673-682.

Hyman BT, Van Hoesen GW, Beyreuther K, Masters CL (1989) A4 amyloid protein immunoreactivity is present in Alzheimer's disease neurofibrillary tangles. Neurosci Lett 101:352-355.

Johnson GVW, Jope RS (1988) Phosphorylation of rat brain cytoskeletal proteins is increased after orally administered aluminum. Brain Res 456:95-103.

Johnson GVW, Cogdill KW, Jope RS (1990) Oral aluminum alters in vitro protein phosphorylation and kinase activities in rat brain. Neurobiol Aging 11:209-216.

Khachaturian ZS (1985) Diagnosis of Alzheimer's disease. Arch Neurol 42:1097-1106.

Kosik KS (1992) Alzheimer's disease: a cell biological perspective. Science 256:780-783

Kosik KS, Orecchio LD, Binder L, Trojanowski JQ, Lee VM-Y, Lee G 
(1988) Epitopes that span the tau molecule are shared with paired helical filaments. Neuron 1:817-825.

Kowall NW, Pendlebury WW, Kessler JB, Perl DP (1989) Aluminuminduced neurofibrillary degeneration affects a subset of neurons in rabbit cerebral cortex, basal forebrain and upper brainstem. Neuroscience 29:329-337.

Landsberg JP, Mcdonald B, Watt F (1992) Absence of aluminum in neuritic plaque cores in Alzheimer's disease. Nature 360:65-68.

Lang E, Szendrei GI, Lee VM-Y, Otvos L Jr (1992) Immunological and conformational characterization of a phosphorylated immunodominant epitope of the paired helical filaments found in Alzheimer's disease. Biochem Biophys Res Commun 187:783-790.

Lee JH, Goedert M, Hill WD, Lee VM-Y, Trojanowski JQ (1993) Tau proteins are abnormally expressed in olfactory epithelium of Alzheimer's disease and developmentally regulated in fetal spinal cord. Exp Neurol 121:93-105.

Lee VM-Y, Trojanowski JQ (1992) The disordered neuronal cytoskeleton in Alzheimer's disease. Curr Opin Neurobiol 2:653-656.

Lee VM-Y, Carden MJ, Trojanowski JQ (1986) Novel monoclonal antibodies provide evidence for the in situ existence of a nonphosphorylated form of the largest neurofilament subunit. J Neurosci 6:850858.

Lee VM-Y, Carden MJ, Schlaepfer WW, Trojanowski JQ (1987) Monoclonal antibodies distinguish several differentially phosphorylated states of the two largest rat neurofilament subunits (NF-H and NF-M) and demonstrate their existence in the normal nervous system of adult rats. J Neurosci 7:3474-4388.

Lee VM-Y, Balin BJ, Otvos L Jr, Trojanowski JQ (1991) A68: a major subunit of paired helical filaments and derivatized forms of normal tau. Science 251:675-678.

Mandelkow EM, Drewes G, Biernat J, Gustke N, Van Lint J, Vandenheede JR, Mandelkow E (1992) Glycogen synthase kinase 3 and the Alzheimer's disease-like state of microtubule-associated protein tau. FEBS Lett 314:315-321.

Mantyh PW, Ghilardi JR, Rogers S, DeMaster E, Allen CJ, Stimson ER, Maggio JE (1993) Aluminum, iron and zinc ions promote aggregation of physiological concentrations of $\beta$-amyloid peptide. J Neurochem 61:1171-1174

Marksbery WR, Ehmann WD (1993) Aluminum and Alzheimer's disease. Clin Neurosci 1:212-218.

Martin RB (1992) Aluminum speciation in biology. In: Ciba Foundation symposium 169, Aluminum in biology and medicine (Williams RMP, ed), pp 5-25. New York: Wiley.

Martyn CN, Barker DJP, Osmond C, Harris EC, Edwardson JA, Lacey RF (1989) Geographical relation between Alzheimer's disease and aluminum in drinking water. Lancet i:59-62.

McLachlan DR, Fraser PE, Dalton AJ (1992) Aluminum and the pathogenesis of Alzheimer's disease: a summary of evidence. In: Ciba Foundation symposium 169, Aluminum in biology and medicine (Williams RMP, ed), pp 87-108. New York: Wiley.

Mori H, Kondo J, Ihara Y (1987) Ubiquitin is a component of paired helical filaments in Alzheimer's disease. Science 235:1641-1644.

Mullan M, Crawford F (1993) Genetics and molecular advances in Alzheimer's disease. Trends Neurosci 16:409-414.

Munoz-Garcia D, Pendlebury WW, Kessler JB, Perl DP (1986) An immunocytochemical comparison of cytoskeletal proteins in aluminum-induced and Alzheimer-type neurofibrillary tangles. Acta Neuropathol (Berl) 70:243-248.

Namba Y, Tomonaga M, Kawasaki H, Otomo E, Ikeda K (1991) Apolipo-protein E immunoreactivity in cerebral amyloid deposits and neurotibrillary tangles in Alzheimer's disease and kuru plaque amyloid in Creutzfeldt-Jakob disease. Brain Res 541:163-166.

Narindrasorasak S, Lowery D, Gonzalez-DeWhitt P, Poorman RA, Greenberg B, Kisilevsky R (1991) High affinity interactions between the Alzheimer's $\beta$-amyloid precursor proteins and the basement membrane form of heparan sulfate proteoglycan. J Biol Chem 266:1287812883.

Perl DP, Brody AR (1980) Alzheimer's disease: x-ray spectrometric evidence of aluminum accumulation in neurofibrillary tangle-bearing neurons. Science 208:297-299.

Perl DP, Good PF (1992) Aluminum and the neurofibrillary tangle: results of tissue and microprobe studies. In: Ciba Foundation symposium 169, Aluminum in biology and medicine (Williams RMP, ed), pp 217-236. New York: Wiley.

Perlmutter LS, Barron E, Saperia D, Chui HC (1991) Association between vascular basement membrane components and the lesions of Alzheimer's disease. J Neurosci Res 30:673-681.

Perry G (1993) Neuritic plaques in Alzheimer's disease originate from neurofibrillary tangles. Med Hypotheses 40:257-258.

Perry G, Friedman R, Shaw G, Chau V (1987) Ubiquitin is detected in neurofibrillary tangles and senile plaque neurites of Alzheimer disease brains. Proc Natl Acad Sci USA 84:3033-3036.

Perry G, Siedlak SL, Richey P, Kawai M, Cras P, Kalaria RN, Galloway PG, Scardina JM, Cordell B, Greenberg BD, Ledbetter SR, Gambett $P$ (1991) Association of heparan sulfate proteoglycan with the neurofibrillary tangles of Alzheimer's disease. J Neurosci 11:3679-3683.

Perry G, Cras P, Siedlak SL, Tabaton M, Kawai M (1992) B Protein immunoreactivity is found in the majority of neurofibrillary tangles of Alzheimer's disease. Am J Pathol 137:711-723.

Perry G, Richey PL, Siedlak SL, Smith MA, Mulvihill P, DeWitt DA, Barnett J, Greenberg BD, Kalaria RN (1993) Immunocytochemical evidence that the $\beta$-protein precursor is an integral component of neurofibrillary tangles of Alzheimer's disease. Am J Pathol 143:15861593.

Picardo P, Yanagihara R, Garruto RM, Gibbs CJ, Gajdusek DC (1988) Histochemical and $\mathrm{x}$-ray microanalytical localization of aluminum in amyotrophic lateral sclerosis and parkinsonism-dementia of Guam. Acta Neuropathol (Berl) 77:1-4.

Saunders AM, Strittmatter WJ, Schmechel D, St George-Hyslop PH, Pericak-Vance MA, Joo SH, Rosi BL, Gusella JF, Crapper-MacLachlan DR, Alberts MJ, Hulette C, Crain B, Goldgaber D, Roses $\mathrm{AD}$ (1993) Association of apolipoprotein $\mathrm{E}$ allele $\epsilon 4$ with latc-onsct familial and sporadic Alzheimer's disease. Neurology 43:1467-1472.

Schmechel DE, Saunders AM, Strittmatter WJ, Crain BJ, Hulette CM, Joo SH, Pericak-Vance MA, Goldgaber D, Roses AD (1993) Increased amyloid $\beta$-peptide deposition in cerebral cortex as a consequence of apolipoprotein E genotype in late-onset Alzheimer's disease. Proc Natl Acad Sci USA 90:9649-9653.

Schmidt ML, Carden MJ, Lee VM-Y, Trojanowski JQ (1987) Phosphate dependent and independent neurofilament epitopes in the axonal swellings of patients with motor neuron disease and controls. Lab Invest 56:282-294.

Schmidt ML, Lee VM-Y, Trojanowski JQ (1990) Relative abundance of tau and neurofilament epitopes in hippocampal neurofibrillary tangles. Am J Pathol 136:1069-1075.

Schmidt ML, Lee VM-Y, Trojanowski JQ (1991) Comparative cpitopc analysis of neuronal cytoskeletal proteins in Alzheimer's disease senile plaque neurites and neuropil threads. Lab Invest 64:352-357.

Scott CW, Fieles A, Sygowski LA, Caputo CB (1993) Aggregation of tau protein by aluminum. Brain Res 628:77-84.

Selkoe DJ (1993) Physiological production of the $\beta$-amyloid protein and the mechanisms of Alzheimer's disease. Trends Neurosci 16:403409.

Selkoe DJ, Liem RKH, Yen SH, Shelanski MK (1979) Biochemical and immunological characterization of neurofilaments in experimental neurofibrillary degeneration. Brain Res 163:235-252.

Shaw G, Chau V (1988) Ubiquitin and microtubule-associated protein tau immunoreactivity each define distinct structures with differing distributions and solubility properties in patients with Alzheimer's disease. Proc Natl Acad Sci USA 85:2854-2858.

Shin R-W, Ogomori K, Kitamoto T, Tateishi J (1989) Increased tau accumulation in senile plaques as a hallmark in Alzheimer's disease. Am J Pathol 134:1365-1371.

Shin R-W, Iwaki T, Kitamoto T, Tateishi J (1991) Hydrated autoclave pretreatment enhances tau immunoreactivity in formalin-fixed normal and Alzheimer's disease brain tissues. Lab Invest 64:693-702.

Shin R-W, Bramblett GT, Lee VM-Y, Trojanowski JQ (1993) Alzheimer disease $\mathrm{A} 68$ proteins injected into rat brain induce codeposits of $\beta$-amyloid, ubiquitin, and $\alpha_{1}$-antichymotrypsin. Proc Natl Acad Sci USA 90:6825-6828.

Siegel N, Haug A (1983) Aluminum interaction with calmodulin. Evidence for altered structure and function from optic and enzymatic studies. Biochem Biophys Acta 744:36-45.

Snow AD, Mar H, Nochlin D, Kimata K, Kato M, Suzuki S, Hasscl J, Wight TN (1988) The presence of heparan sulfate proteoglycans in the neuritic plaques and congophilic angiopathy in Alzheimer's disease. Am J Pathol 133:456-463.

Snow AD, Sekiguchi R, Nochlin D, Fraser P, Kimata K, Mizutami A, Arai M, Schreier WA, Morgan DG (1994) An important role of heparan sulfate proteoglycan (Perlecan) in a model system for the 
deposition and persistence of fibrillar $A \beta$-amyloid in rat brain. Neuron 12:219-234.

Spillantini MG, Goedert M, Jakes R, Klug A (1990) Topographical relationship between $\beta$-amyloid and tau protein epitopes in tanglebearing cells in Alzheimer's disease. Proc Natl Acad Sci USA 87: 3952-3956.

Springall DR, Hacker GW, Grimelius L, Polak JM (1984) The potential of the immunogold-silver staining method for paraffin sections. Histochemistry 81:603-608.

Stern AJ, Perl DP, Munoz-Garcia D, Good PF, Abraham C, Selkoe DJ (1986) Investigation of silicon and aluminum content in isolated senile plaque core by laser microprobe mass analysis (LAMMA). J Neuropathol Exp Ncurol 45:361.

Stern RA, Otvos L Jr, Trojanowski JQ, Lee VM-Y (1989) Monoclonal antibodies to a synthetic peptide homologous with the first 28 amino acids of Alzheimer's disease $\beta$-protein recognize amyloid and diverse glial and neuronal cell types in the central nervous system. Am J Pathol 134:973-978.

Tohyama T, Lee VM-Y, Rorke LB, Trojanowski JQ (1991) Molecular milestones that signal axonal maturation and the commitment of human spinal cord precursor cells to the neuronal or glial phenotype in development. J Comp Neurol 310:285-299.

Trojanowski JQ (1983) Native and derivatized lectins for the in vivo studies of neuronal connectivity and neuronal cell biology. J Neurosci Methods 9:185-204.

Trojanowski JQ, Schuck T, Schmidt ML, Lee VM-Y (1989) Distribution of tau proteins in the normal human central and periphcral nervous system. J Histochem Cytochem 37:209-215.

Trojanowski JQ, Mawal-Dewan M, Schmidt ML, Martin J, Lee VMY (1993a) Localization of the mitogen activated protein kinase ERK2 in Alzheimer's disease neurofibrillary tangles and senile plaque neurites. Brain Res 618:333-337.

Trojanowski JQ, Schmidt ML, Shin R-W, Bramblett GT, Rao D, Lee VM-Y (1993b) Altered tau and neurofilament proteins in neurod- egenerative diseases: diagnostic implications for Alzheimer's disease and Lewy body dementias. Brain Pathol 3:45-54.

Trojanowski JQ, Schmidt ML, Shin R-W, Bramblett GT, Goedert M, Lee VM-Y (1994) PHF (A68): from pathological marker to potential mediator of neuronal dysfunction and degeneration in Alzheimer's disease. Clin Neurosci 1:184-191.

Troncoso J, Sternberger NH, Sternberger LA, Hoffman PN, Price DL (1986) Immunocytochemical studies of neurofilament antigens in the neurofibrillary pathology induced by aluminum. Brain Res 364 : 295-300.

Vulliet R, Halloran SP, Braun RK, Smith AJ, Lee G (1992) Prolinedirected phosphorylation of human tau protein. J Biol Chem 267 22570-22574.

Webb J, Multani JS, Saltman P, Beach NA, Gray HB (1973) Spectroscopic and magnetic studies of iron (III) phosvitins. Biochemistry 12:1797-1802.

Wisniewski HM, Moretz RC, Iqbal K (1986) No evidence for aluminum in etiology and pathogenesis of Alzheimer's disease. Neurobiol Aging 7:532-535.

Wisniewski T, Frangione B (1992) Apolipoprotein E: a pathological chaperone protein in patients with cerebral and systemic amyloid. Neurosci Lett 135:235-238.

Wolozin BL, Pruchnicki A, Dickinson DW, Davies P (1986) A neuronal antigen in the brains of Alzheimer patients. Science 232:648650.

Yachnis AT, Rorke LB, Lee VM-Y, Trojanowski JQ (1993) Expression of neuronal and glial polypeptides during histogenesis of the human cerebellar cortex including observations on the dentate nucleus. J Comp Neurol 334:356-369.

Yamamoto H, Saito Y, Yasugawa S, Miyamoto E (1990) Dephosphorylation of $\tau$ factor by protein phosphatase $2 \mathrm{~A}$ in synaptosomal cytosol fractions, and inhibition by aluminum. J Neurochem 55:683690. 